\title{
Contingency and Contracts: A Philosophy of Complex Business Transactions
}

Jeffrey M. Lipshaw

Follow this and additional works at: https://via.library.depaul.edu/law-review

\section{Recommended Citation}

Jeffrey M. Lipshaw, Contingency and Contracts: A Philosophy of Complex Business Transactions, 54

DePaul L. Rev. 1077 (2005)

Available at: https://via.library.depaul.edu/law-review/vol54/iss4/4

This Article is brought to you for free and open access by the College of Law at Digital Commons@DePaul. It has been accepted for inclusion in DePaul Law Review by an authorized editor of Digital Commons@DePaul. For more information, please contact digitalservices@depaul.edu. 


\title{
CONTINGENCY AND CONTRACTS: A PHILOSOPHY OF COMPLEX BUSINESS TRANSACTIONS
}

\author{
Jeffrey M. Lipshaw*
}

We proceed on the assumption that the true and the good, and just possibly the beautiful, coincide. Where they do not, we demand an account. The urge to unite is and ought stands behind every creative endeavor. Those who seek to unite them by force usually do more harm than they set out to prevent. Those who never seek to unite them do nothing at all. ${ }^{1}$

A purely stable world permits of no illusions, but neither is it clothed with ideals. It just exists. To be good is to be better than; and there can be no better except where there is shock and discord combined with enough assured order to make attainment of harmony possible. ${ }^{2}$

\section{INTRODUCTION}

The prevailing literature on contract theory does not adequately address the way real world lawyers address uncertainty in complex business transactions. I attribute this to the constraints imposed by thinking in legal models, the dominant tendency to turn to economics for analysis and normative prescription, and the focus on adjudicative issues of hindsight interpretation. The behavior of lawyers and business people in the course of complex commercial transactions and re-

* Adjunct Professor, Indiana University School of Law-Indianapolis; Senior Vice President, General Counsel \& Secretary, Great Lakes Chemical Corporation. A.B., 1975, University of Michigan; J.D., 1979, Stanford University. I wish to acknowledge the following individuals for their encouragement, comments, and constructive criticism: Susan Neiman, Richard Posner, Linda Ross Meyer, Daniel Cole, Jonathan Cohen, Jeffrey Liss, Susannah Mead, and Alene Franklin.

1. Susan Neiman, Evil in Modern Thought 322 (2002). Prefacing with a quote from a book about evil is not as far-fetched as it may seem. Neiman's work is a revisionist history of modern philosophy, arguing that a meaningful understanding of the great thinkers since the Enlightenment can be based on how they approached the question: Why is it that things in the world go very, very wrong? Coming to terms with great natural or moral evils, like the Lisbon earthquake or the Holocaust, respectively, is for philosophers like Neiman. Business lawyers rarely deal with true evil (although we may feel that way in the twentieth hour of a day with a tough adversary). We deal with more mundane things going inexplicably wrong, like the lender reneging on its commitment out of the blue, or the stock market crash of October 1987 causing an acquisition to fall through. Nevertheless, the same philosophy can be instructive. That is the lesson of this Article.

2. John Dewey, Experience And Nature 62 (1929). 
lationships suggest homo economicus is not the only model of human behavior, even in economic relationships: This is particularly true in complex business transactions, like merger and acquisition (M\&A) or venture capital work. ${ }^{3}$

Commercial uncertainty, and the law's response to it, is only a subset of the broader philosophical issue of contingency. How the law and lawyers deal with transactional uncertainty is merely a subset of how we as human beings come to terms with the uncertainty of the world, individually or socially. When we write contracts, we deal with contingent events, those with "[t]he property of not having to occur." Some scholars have recognized that the law of contracts is not the only way business people may attempt to deal with contingency. ${ }^{5}$ Very few have tried to address it as a matter of philosophy. I am neither a professional economist nor a philosopher, but I will nevertheless try to answer Martha Nussbaum's call to link the real world of dealmaking to historic sources of philosophy and jurisprudence. ${ }^{6}$ First, I will counter those current thinkers who believe, like some of their philosophical forebears, that they have found the one predominant way of thinking about the world. Second, this Article suggests, in the philosophical tradition, alternative cross-disciplinary contexts for law and lawyers. Finally, I suggest a role for lawyers in completing deals that invokes a (perhaps unscientific) pragmatic idealism. ${ }^{7}$

3. In other contexts, see Jeffrey M. Lipshaw, Sarbanes-Oxley, Jurisprudence, Game Theory, Insurance and Kant: Toward a Moral Theory of Good Governance, 50 WAYNE L. REv. (forthcoming 2005) (manuscript at 33-41), available at http://ssrn.com/abstract=576761 (discussing how corporate board responses to Sarbanes-Oxley and the nature of board service suggest, from the standpoint of philosophy, that directors respond to law, economics, and morality simultaneously, notwithstanding the contradictions that may exist among them); Lynn A. Stout, In Praise of Procedure: An Economic and Behavioral Defense of Smith v. Van Gorkom and the Business Judgment Rule, $96 \mathrm{Nw}$. U. L. REv. 675, 683-87 (2002) (noting that rational actor assumptions of economic analysis fail to account for "other-regarding" or altruistic behavior on corporate boards, and observing how unfashionable it is to account for behavior with notions of responsibility, obligation, or honor).

4. Anthony Flew, A Dictionary of Philosophy 74-75 (2d ed. 1999).

5. See generally, e.g., Eric A. Posner, Law and Social Norms (2000); David Charny, NonLegal Sanctions in Commercial Relationships, 104 HARv. L. Rev. 375 (1990); Stewart Macaulay, An Empirical View of Contract, 1985 WIs. L. Rev. 465 [hereinafter Macaulay, Empirical View]; Stewart Macaulay, Non-Contractual Relations in Business: A Preliminary Study, 28 АM. Soc. Rev. 55 (1963) [hereinafter Macaulay, Non-Contractual Relations]; Mark C. Suchman, The Contract as Social Artifact, 37 LAw \& Soc'y Rev. 91 (2003).

6. Martha C. Nussbaum, Flawed Foundations: The Philosophical Critique of (a Particular Type of) Economics, 64 U. CHI. L. REv. 1197, 1214 (1997).

7. When I refer to "moral philosophy" in this Article, I am generally not referring to normative ethics-how we should behave in a particular circumstance. I am more concerned with that aspect of philosophy, also referred to as "moral philosophy," that is "not directly concerned with the content of any particular form of moral life, whether real or imaginary, but with what the general logical rules of any morality or any moral argument ... must be." FLEw, supra note 4, at 
One repeating pattern in the history of ideas is the attempt, futile in my view, to explain away all contingency, or on the other hand, to throw up one's hands and conclude that the urge to explain it away, or even to see order in the chaos, is misplaced mysticism, an accident of biology, or the residue of something too spicy we ate for dinner. Understanding the persistence of contingency in all its forms, without giving up, may be the single most important thing lawyers can bring to leadership. Nevertheless, the body of American philosophy most associated with the problem of contingency, the pragmatism of William James and John Dewey (also associated with the legal pragmatism of Justice Oliver Wendell Holmes, Jr.), has been co-opted by jurisprudential scholars who would remove moral philosophy as a legitimate source of thought about lawyers and their place in society, much less complex commercial interactions, and replace it with what purports to be science. ${ }^{8}$

Lawmakers rely on a model of law as regulator of behavior-just as economists model the rational actor, sociologists model the relationship of individuals and groups, or psychologists model the workings of the mind. Disinterested observers would likely suggest the worth of a model is its ability to predict and explain real world behavior; no model is a perfect representation of the real world, and some truth no doubt underlies each.

I will now broaden the inquiry with a philosophic assessment of the spirit and manner in which we construct and advocate the models themselves, particularly as they affect working lawyers, in the black versus white, good versus evil, us versus them of today's political and intellectual milieu. The history of ideas is nothing if not a dialectic of faith and skepticism, experience and reason, contingency and determinism, the community and the organization-all models intended to make sense of the world. Yet it is testimony to our species' short memory or persistence that these dichotomous models are either reconciled or rediscovered in every generation.

112-14. I am also seeking to obtain a better explanation of what moves us in a particular circumstance, and with that explanation, suggest ways to guide our practical action.

8. I have in mind the view of some within the law and economics movement that reputation, trust, and goodwill are economic goods-the value of which homo economicus may, in the course of rational calculation, seek to maximize. See, e.g., PoSNER, supra note 5, at 191-92. Professor Eric Posner emphasizes

that because sometimes a person's principled claims will constrain his behavior, the person will cheat less often (though he will cheat if the payoff is high enough) than he would if he did not make principled claims. Therefore, claims to be principled actually may produce social benefits-by reducing the amount of cheating-even though they do not ensure or reflect principled behavior. 
The very nature of how we reason about those dichotomies has led, paradoxically, to our present incarnation of conflicting certainties. In a phrase common to lawyers-it takes very little for our reason to have us sliding down a slippery slope, whether or not there ever was a hill. Against the "either-or" to which our reason tends, leadership in law or business (and one hopes in politics) entails understanding the difference between the use of reason on one hand, and being reasonable on the other. In the real and practical short run, as problem-solvers and advocates, we must find answers, resolve hard cases, fire and hire, and satisfy Wall Street's expectations. But, with apologies to Robert Louis Stevenson, as leaders and policymakers, we are ultimately better off traveling hopefully than deluding ourselves that we have arrived. ${ }^{9}$ Perfectability can be worse than a myth; believing it is achievable may be a disease. Even the current proponents of a form of legal pragmatism (e.g., Judge Richard Posner), unlike their philosophic forebears, fall into this trap. They no longer espouse even a healthy agnosticism about moral philosophy as a guide; they are certain it is bankrupt. ${ }^{10}$

I do not intend to demonstrate, for example, that there are no insights from economic analysis of law in the world of complex deals. Indeed, I believe it is a fundamental truth that people act in their own interest, and that as to aspects of the deal process, they are primarily rational actors. But $\mathrm{I}$ also believe it is a fundamental truth that something compels us to regard others with a sense of honor, obligation, and responsibility. What $I$ will argue is that both truths are apparent on a regular basis, regardless of the governing law or rational actor economics in complex commercial arrangements. Human beings do not check at the office door their impulse to find ways to make sense of why things go wrong in the world and to impose order on the chaos-whether through contract, personal relationships, self-deception, economic analysis, or moral philosophy. Contracts are one way to deal with contingency. Submitting disputes to a judge when we disagree is another. Neither is exclusive.

9. "To travel hopefully is a better thing than to arrive." Quotations by Author, The Quotations Page, at http://www.quotationspage.com/quotes/Robert_Louis_Stevenson/ (last visited Mar. 31, 2005).

10. As Martha Nussbaum has noted, Aristotle had only a qualified belief that conceptual thought progressed over time:

Aristotle also noticed ... that the passion for science and simplicity frequently lead highly intelligent people into conceptual confusion and an impoverished view of the human world. So he did not think that progress was inevitable, and one of his great arguments for reading was that it could remind us of conceptual complexities we might otherwise efface, in our zeal to make life more tractable than it is.

Nussbaum, supra note 6, at 1214. 
Ironically, the pragmatic impulse (like Judge Posner's) stems from the same fully understandable aversion to absolutism that motivated Kant's treatment of-but refusal to reject-idealism. The philosophical pragmatists (James, in particular) thought:

[T] hat the mistake most people make about beliefs is to think that a belief is true, or justified, only if it mirrors 'the way things really are'- that (to use one of James's most frequent targets, Huxley's argument for agnosticism) we are justified in believing in God only if we are able to prove that God exists apart from our personal belief in him. ${ }^{11}$

In the trenches where law intersects with complex business, where little is adjudicated but much is accomplished, the pragmatists are right: Permitting the dictatorship of a single idea over the use of common sense to get things done is the bane of every businessperson who has said to a lawyer, "all you tell me is "no." 12 But I argue for something more. Understanding how people respond-seeing them, in Kant's articulation, as ends and not means ${ }^{13}$ - and having vision or trust when the formula of the legal documents will not suffice has value in the world, and hence is true, regardless of whether it is measurable. I believe measurable and incommensurable ideas have value. It is simply a better world when we acknowledge both. Leaders we want to encourage will recognize it; so will lawyers who get deals done. Posner's "pragmatic skepticism" gets two-thirds of the way

11. Louis Menand, The Metaphysical Club 356 (2001).

12. Some law and economics scholars recognize at least the perception of the empirical observation, if not what I will suggest are its philosophical roots. One such article argues that " $[\mathrm{t}] \mathrm{he}$ tension between lawyers and business people is part of the folklore. Lawyers complain that business people do not plan carefully enough against future contingencies; business people complain that lawyers' caution interferes with valuable deals." Karen Eggleston et al., The Design and Interpretation of Contracts: Why Complexity Matters, 95 Nw. U. L. Rev. 91, 126 n.102 (2000); see also James C. Freund, Anatomy of a Merger 4 n.1 (1975). Freund notes:

A recent advertisement appearing in The Wall Street Journal for a book entitled WINNing Through INTIMIDATION contained the following text: "Have you ever had a deal blow up solely because of an attorney? ... [Y]ou must face the reality that attorneys have been, are, and, unfortunately, probably always will be a major obstacle in just about every significant business transaction that takes place. ... [Y] ou must develop specific techniques ... for protecting your flanks from the deal-killing expertise of the other side's attorney."

Id.; see also Mike France, A Compelling Case for Lawyer-CEOs, Bus. WK., Dec. 13, 2004, at 88 ("Business attorneys are often considered the 'vice-presidents of No,' says Jeffrey A. Sonnenfeld, associate dean of executive programs at Yale School of Management.").

13. "[T]he fundamental principle of all maxims of action must be that the subject of all ends, i.e. the rational being himself, be never employed merely as means, but as the supreme condition restricting the use of all means, that is in every case as an end likewise." IMMANUEL KANT, Fundamental Principles of the Metaphysics of Morals, in BAsIC WRITINGs OF KANT 144, 195 (Allen W. Wood ed., 2001). 
there by rejecting absolutism and focusing on real world results, ${ }^{14}$ but fails to account for that slippery and probably incommensurable thing we sense as vision or leadership.

In Part II, I summarize significant cross-disciplinary approaches to legal contingency (or uncertainty) in commercial contexts-economic and societal-and point out their implications for working lawyers. Neither economic theories of optimum risk allocation (the Coase theorem) nor strategic behavior are particularly helpful to dealmakers, other than in limited circumstances where rational behavior can be presumed. The law and society movement aptly characterizes the limited role of contract in commercial behavior, but offers no practical advice. I further offer philosophy, and particularly the contrasting views of Hume, Kant, and the American pragmatists (James and Dewey) as an alternative and generally disregarded discipline that may provide insight into the creative process of making a deal.

In Part III, I outline particular examples of contingency in the negotiation of complex acquisitions or venture capital start-ups, and critique a prevalent view of the role of moral philosophy in the lawRichard Posner's "pragmatic skepticism" and his rejection of the application of any universal moral standards to the law. I also contrast that skepticism with the empirical evidence in the literature of modern business management and leadership that people do respond in viscerally utilitarian environments to non-utilitarian appeals. I suggest that there are both utilitarian and non-utilitarian reasons for a return to the fashion of assessing not just the economic, but the philosophic basis of behavior. Finally, I make some normative proposals and set forth two (not so) hypothetical situations, suggesting that deal lawyers would be well served by at least studying, if not adopting, a philosophy of pragmatic idealism.

\section{The Relationship of Contingency, Law, and Philosophy to Complex Commercial Relationships \\ A. Cross-Disciplinary Views of Contingency in Complex Transactions}

When we make a promise, or enter into a contract, we are looking forward and seeking to reduce contingency. ${ }^{15}$ I can only guess what

14. See generally Richard A. Posner, Law, Pragmatism, and Democracy (2003).

15. In ordinary usage, uncertainty and contingency are equivalent. The dictionary defines contingency as "something whose occurrence depends on chance or uncertain conditions; a possible, unforeseen, or accidental occurrence." Webster's New WORLd Dictionary 301 (3d Coll. ed. 1988). In this Article, I use the term "contingency" because of its philosophical connotations. 
the price of wheat or the value of the Euro will be in ninety days, but when I contract with you to buy wheat or Euros, I have dealt with contingencies that might occur: Severe weather that wipes out most of the wheat crop, or an unanticipated interest rate hike by the European central banks.

What are the contingencies that contracts attempt to address in a complex transaction? The sale agreement for an ongoing multi-billion dollar business may contain dozens of representations and warranties (which to one degree or another must be materially true at the time of execution and closing), pre-closing covenants, conditions to closing, and post-closing covenants and indemnifications. ${ }^{16}$ Conditions to closing not in the direct control of the parties might include the absence of an injunction or restraining order, the obtaining of consents to the assignment of material contracts, licenses or permits, competition law clearances, other governmental approvals (such as foreign investment filings), securing of financing, and depending on how the clause is drafted, no material adverse change in the business itself or in conditions surrounding the business. ${ }^{17}$ In a leveraged buyout with syndicated financing, the loan agreement may typically run to a hundred pages, with dozens of representations and warranties, affirmative and negative covenants, conditions to the initial closing, and subsequent cash advances. ${ }^{18}$

The world of start-up businesses and venture capital is almost defined by contingency. ${ }^{19}$ The fundamental document in a venture capital transaction is the term sheet: It summarizes the financial and legal terms and conditions of the deal, and serves as the basis for the more complex agreements to come-for example, preferred stock terms, loan agreements, and shareholder agreements. ${ }^{20}$ The term sheet will cover the rights and duties of the entrepreneur and investor as to

16. See, e.g., Asset Purchase Agreement Dated as of February 29, 1996 Among Robert Bosch GmbH and the Other Purchasers Named Herein and AlliedSignal, Inc. and the Other Sellers Named Herein, filed with Form 8-K (Apr. 12, 1996), available at http://www.sec.gov/Archives/ edgar/data/773840/0000773840-96-000005.txt. This deal involved AlliedSignal's sale of the Bendix brake business to Bosch for $\$ 1.5$ billion. The deal involved assets in nine countries and seven states.

17. Id. at $44-46$.

18. See, e.g., U.S. $\$ 36,500,000$ Loan Agreement Dated as of February 2, 1990 Among Automotive Plastic Technologies, Inc. as Borrower, the Lenders Named Herein as Lenders and General Electric Capital Corporation as Agent and Lender (on file with the DePaul Law Review).

19. Constance E. Bagley \& Craig E. Dauchy, The Entrepreneur's Guide to BusiNESS LAW 3 (2003) (stating that "[m]ost entrepreneurs and their backers are not risk seekers; rather they are risk takers who attempt to manage the risks inherent in pursuing new opportunities by making staged commitments and conducting a series of experiments" (footnote omitted)).

20. Alex Wilmerding, Term Sheets and Valuations 7 (2003). 
rights, preferences, and privileges of preferred stock, liquidation preferences, redemption, conversion, dilution in the event of future investment, voting, board composition and information rights, stock registration rights, rights of first refusal, stock options, and many other matters. ${ }^{21}$ As we will see, in the jargon of economists and game theorists, what these transactions (and their governing contracts) have in common are repeated outcomes (the players encounter each other over and over again) ${ }^{22}$ and "insufficient[ ] state contingen[cies]" (the contracts do not completely address all of the possible future states of the world). ${ }^{23}$ The more varied and more repeated the outcomes are between beginning and end, the more risk and contingency the transaction will contain. The number of fixed contractual resolutions, such as redemption or conversion options in preferred stock, or deferred contractual resolutions (e.g., agreements to negotiate later in good faith, requirements of consent "not unreasonably to be withheld," and deliberate ambiguity), are as unlimited as the ingenuity of lawyers and their clients.

\section{The Law and Economics Approach \\ a. Efficiency}

The law of contracts is concerned with enforcing entitlements (legally protected rights) that arise between parties that have obligated themselves to each other by promise. ${ }^{24}$ Certainly the most voluminous body of scholarship within the "four corners" of contract law is the work attempting to assess contract law in light of economic theory. ${ }^{25}$ One use of economic analysis is to design rules of adjudication that maximize social welfare in the event of a dispute (absent agree-

21. Id. at $31-81$.

22. Eggleston et al., supra note 12, at 115-19.

23. See Ian Ayres \& Robert Gertner, Strategic Contractual Inefficiency and the Optimal Choice of Legal Rules, 101 YALE L.J. 729, 731 (1992).

24. See generally Jason Scott Johnston, Default Rules/Mandatory Principles: A Game Theoretic Analysis of Good Faith and the Contract Modification Problem, 3 S. CAL. INTERdisc. L.J. 337 (1993).

25. Any survey of this literature begins with Richard Posner's seminal text on economic analysis of law, which covers far more than contracts. See generally Richard A. Posner, Economic ANALYsis of LAw (6th ed. 2003). Posner's law and economics approach is also evident in his influential judicial decisions, the hallmark of which is "only one primary concern-efficiency through freedom of contract." Lawrence A. Cunningham, Cardozo and Posner: A Study in Contracts, 36 WM. \& MARY L. REv. 1379, 1381 (1995). Judge Posner himself surveys the economic literature on contracts and contract law in a recent article. Richard A. Posner, The Law and Economics of Contract Interpretation, at $1 \mathrm{nn} .2-3$ (Nov. 2004), available at http://ssrn.com/abs tract $=610983$. In this Article, I refer to the work of some of the most distinguished law and economics scholars writing today, such as Alan Schwartz, Robert Scott, Avery Wiener Katz, Eric A. Posner, and Richard Craswell. 
ment of the parties to some other resolution). Another form of analysis attempts to predict the outcome of strategic behavior or bargaining through game theory models. I believe both are instructive as to specific aspects of the dealmaking process, but neither is sufficient to explain fully how people deal (or should deal) with contingency in complex transactions because their conditions are rarely met in the real world.

\section{i. The Coase theorem}

Ronald Coase, the 1991 Nobel Prize winner in economics, created the law and economics model by restating the way in which legal rules should address externalities, that is, costs not borne by an economic actor. $^{26}$ If a manufacturer of widgets pollutes, for example, and does not bear the cost of clean-up, and the pollution imposes a cost on others, then the manufacturer may make too many widgets, all other things being equal. He may produce widgets whose total societal cost exceeds their value, and that result is inefficient. ${ }^{27}$ As to contracts, the Coase theorem says that as long as the parties involved can readily make and enforce contracts in their mutual interest, neither direct regulation nor tax impositions (to internalize the cost) are necessary to achieve an efficient outcome. ${ }^{28}$ The conditions of his theorem are as follows: (1) There are no transaction costs (i.e., any agreement that can be made will be made, and can be enforced without cost); and (2) there is a clear and understood set of rules defining, in the absence of the agreement, who will bear those costs that might otherwise be externalities. ${ }^{29}$ If those conditions are met, then it does not matter how the default rules actually allocate the liabilities. The parties will use the private ordering of a contract to determine who bears the cost, and the outcome will be efficient. ${ }^{30}$

Economic analysis of law goes a step further and addresses the rules the law should impose in the absence of a contrary private allocation by contract. In the absence of a clear indication of the parties' intention (which economic analysis would generally presume to militate toward an efficient result), economic analysis advocates would have the liability fall on the party best able to avoid, insure against, or bear the cost. $^{31}$ Thus, in the absence of an explicit risk of loss term, a seller

26. David D. Friedman, The Swedes Got It Right, at http://www.daviddfriedman.com/Academic/Coase_World.html (last visited Mar. 31, 2005).

27. Id.

28. Id.

29. Id.

30. Id.

31. Id. 
who had transferred title but retained the goods in its warehouse would bear the risk of a fire loss on the assumption that the seller could prevent or insure against the fire at a lower cost than the buyer. $^{32}$

Are the transaction cost conditions of the Coase theorem met in a complex deal negotiation? From one practitioner's intuitive standpoint, the answer is both "yes" and "no." As to the negotiation of specific provisions, yes, the theorem has some explanatory power. Default rules do address specific externality issues that arise within the broader negotiation of the transfer or creation of a business. ${ }^{33} \mathrm{In}$ deed, accepting or contracting around the way those rules allocate risk and liability is a major part of deal negotiating and lawyering. Efficiency maximization, social welfare, or some other desirable function ought to play a role setting forth default obligations to third parties as between buyers and sellers of businesses, and economic analysis plays an important part in assessing whether the rules work. ${ }^{34}$ It is perfectly reasonable that default rules in these areas would be based, in the absence of other agreements between the parties, on an allocation of liability to the parties best able to avoid, bear, or insure against the socially unacceptable consequence. ${ }^{35}$ Finally, in comparison to the to-

32. POSNer, supra note 25 , at $96-97$.

33. Just a few examples are environmental and product liability successor liability rules, state laws defining what constitutes a continuing business for the purpose of unemployment and other social benefits, post-employment benefit plan obligations under the Consolidated Omnibus Budget Reconciliation Act (COBRA), 29 U.S.C. \$ 1162 (2000), and workers' compensation statutes.

34. See Cass R. Sunstein, On Philosophy and Economics, 19 Quinnipiac L. Rev. 333, 334 (2000). Sunstein argues for a reconciliation of economists and philosophers, focusing on the ability of economic analysis to assess the efficacy of the positive or prescriptive aspects of law. Id. He defines the "prescriptive" work of economics as something less than full-fledged normative assessment of what the law should be. "Economists are ... helpful in giving accounts of how law comes into being and in showing the best way to achieve specified ends. At the more normative level, they are most helpful in showing that if some $\mathrm{X}$ is the goal, some instrument $\mathrm{Y}$ will or will not achieve it." Id.

35. My experience is that good deal lawyers frequently and consciously use the ability to avoid or insure against risk as a negotiation tactic. For example, buyers of businesses have distinctly different attitudes toward the allocation of risk as between onsite and offsite environmental liability. Usually, large corporations have first-rate environmental departments and are capable of doing Phase I and Phase II environmental studies on a defined piece of property. It is not unusual for the result of a negotiation to be that the seller will retain liability for known onsite problems, and the buyer will assume the risk (fully or partially) for unknown problems. This is because due diligence bounds the reasonable risk. On the other hand, offsite liability is determined under the federal superfund laws. Comprehensive Environmental Response, Compensation, and Liability Act, 42 U.S.C. $\S \S 9601-9675$ (2000). That means that the owner of a piece of property can be responsible for contributing to the clean-up of a dump site, often miles from the purchased property, as to which there may be no onsite records or boundaries within which to conduct due diligence. Most buyer's counsel will draw a line in the sand against the assumption of this liability. The statement in the negotiation usually goes something like: "[W]e have no 
tal cost of a typical transaction (hundreds of thousands or millions of dollars in legal, accounting, economist, and other fees), negotiating any particular element of the agreement has a minimal marginal cost.

As to the deal as a whole, the answer would appear to be "no." Among the various transaction costs detailed in the literature are bounded rationality, ${ }^{36}$ asset specificity, ${ }^{37}$ information impactedness, ${ }^{38}$ asymmetrical information distribution, ${ }^{39}$ moral hazard, ${ }^{40}$ opportunism, ${ }^{41}$ and plasticity. ${ }^{42}$ Suffice it to say that all of those costs are, to a greater or lesser degree, present in any acquisition or venture capital

way of knowing where you or your predecessors took your waste offsite, you have or should have had the better opportunity to avoid this cost, and you should bear the risk, no matter upon whom the law puts the statutory liability." Similar arguments can be, and are, made with respect to severance liability, workers' compensation, COBRA benefits, and other costs. For further examples in the context of specific representations and warranties, see FrEUND, supra note 12, at 234-80.

36. "Bounded rationality refers to human behavior that is 'intendedly rational, but only limitedly so'... ." Olliver E. Williamson, Markets and Hierarchies: Analysis and Antitrust Implications 21 (1975) (quoting Herbert A. Simon, Administrative Behavior, at xxiv (2d ed. 1961)). "Simon observes in this connection that 'it is only because individual human beings are limited in knowledge, foresight, skill, and time that organizations are useful instruments for the achievement of human purpose."' Id. (quoting Herbert A. Simon, Models of MAN 199 (1957)).

37. This refers to whether assets are specialized to a particular use or transaction. Categories of asset specificity are: site specificity (e.g., manufacturing assets located in close proximity to reduce inventories), physical asset specificity (e.g., specialized tools and dies), and human asset specificity (e.g., know-how). See Oliver E. Williamson, The Economics of Organization: The Transaction Cost Approach, 87 AM. J. Soc. 548, 555 (1981).

38. This "is a derivative condition that arises mainly because of uncertainty and opportunism, though bounded rationality is involved as well. It exists when true underlying circumstances relevant to the transaction, or related set of transactions, are known to one or more parties but cannot be costlessly discerned by or displayed for others." WILliamson, supra note 36, at 31 .

39. Parties to a transaction have uneven access to relevant information.

40. In economic terminology, moral hazard does not have moralistic overtones. It refers to the lack of observability of contingencies and the consequence of hidden, unverifiable action within contractual relationships. Armen A. Alchian \& Susan Woodward, The Firm Is Dead; Long Live the Firm: A Review of Oliver E. Williamson's The Economic Institutions of Capitalism, 26 J. Econ. Lit. 65, 68 (1988).

41. Alchian \& Woodward note:

Opportunism follows from bounded rationality plus self-interest. When a conflict arises between what people want and what they have agreed to do for others, they will act in their own interest insofar as it is costly for others to know their behavior . . . . Opportunism ... includes honest disagreements. Even when both parties recognize the genuine goodwill of the other, different but honest perceptions can lead to disputes that are costly to resolve.

Id. at 66 .

42. "We call resources or investment[s] 'plastic' to indicate that there is a wide range of discretionary, legitimate decisions within which the user may choose." Id. at 69. 
transaction. ${ }^{43}$ Accordingly, the explanatory or normative power of the theorem at that level of complexity must be limited.

\section{ii. Incompleteness and complexity}

A sampling of more recent economic analysis scholarship bearing most closely on contingent and complex business transactions demonstrates its limitations. The primary focus of the work has been the role of the courts in supplying necessary terms of the contract that the parties, for whatever reason, have omitted.

In 1992, Professors Ian Ayres and Robert Gertner demonstrated the inordinate complexity of attempting to posit particular default rules (those a court would supply in the absence of specification by the parties) in a way that would predictably maximize economic social welfare. ${ }^{44}$ They distinguished legal and economic forms of incompleteness. From the standpoint of legal scholars, a contract to sell goods is "obligationally incomplete" if, in all future states of the world, a term of the obligation is missing. 45 So, for example, if the contract is for the sale of widgets and neglects to specify the place of delivery, it is obligationally incomplete. ${ }^{46}$ Economists look at incompleteness differently. The contract may be obligationally complete but fail to realize the potential gains from trade in all future states of the world: "These contracts are considered 'contingently' incomplete or "insufficiently state contingent." 47 If the contract is obligationally complete (i.e., it is legally enforceable), a party may have incentives, depending on the state of the world, either to renegotiate the contract or to breach it. ${ }^{48}$

43. In these terms, there is: (1) bounded rationality because neither founders nor venture capitalists are fully able to predict whether a start-up technology will succeed; (2) asset specificity because what tends to be unique about the venture is the skill of the founder; (3) information impactedness because persuading investors of the value of the business is not costless; (4) asymmetric information because the founder knows more about the technology (generally) than the investors; (5) moral hazard because of the limited ability even of a board of directors to observe the founder's day-to-day operation of the company; (6) potential for opportunism as the parties perceive the original idea to be more or less valuable than originally thought; and (7) plasticity because of the wide range of decisions available to the business.

44. Ayres \& Gertner, supra note 23, at 729.

45. Id. at 730 .

46. Id.

47. Id.

48. Id. For example, see the facts in Big Horn Coal Co. v. Commonwealth Edison Co., 852 F.2d 1259 (10th Cir. 1988). There, an electric utility and a coal mine executed a long-term contract for the supply of millions of tons of low-sulfur coal. Id. at 1261. The contract, made in the wake of the Arab oil embargo of the early 1970s and the passage of the Clean Air Act, was exceedingly complex, with a multi-variable price escalation clause, detailed specifications for the coal (BTU content, ash content, etc.), and a force majeure provision that called for different remedies on the happenstance of different causes of a failure of delivery. Id. at 1261-64. In the 
Ayres and Gertner pointed out the difficulties in attempting to maximize social welfare through the imposition of contract default rules to make contracts more contingently complete. Their model is based on the default rule established in Hadley v. Baxendale: ${ }^{49}$ A carrier is only liable to a shipper for the foreseeable consequential damages of a delayed shipment. ${ }^{50}$ They concluded that, when contracting around a default is costly (for example, offering alternative contracts with range of guarantees against delay), a default rule can potentially induce inefficiencies such as:

- Precaution: For shippers who would assign a low value to the shipment, a liberal consequential damages default rule would cause the carrier to spend too much to avoid delay; for shippers who assign a high value, a default rule of foreseeability would induce the carrier to spend too little.

- Failure to deal with low-end shippers: If the default rule is set at liberal consequential damages and there is a substantial difference between high-value shippers and low-value shippers, carriers may simply set a price so high that only high-value shippers will use the carrier.

- Transaction Costs: For shippers who would assign a low value to the shipment, a liberal consequential damage default would cause the carrier to spend to contract around the default rule. ${ }^{51}$

ensuing ten years after the execution of the contract, two things significantly changed the state of the world: (1) The spot price of equivalent low-sulfur coal dropped to about eight dollars per ton, compared to the then applicable contract price (after escalation) of about fifteen dollars; and (2) the utility made a subsequent decision to license and build nuclear facilities. Although the lawsuit was the utility's attempt to have a court declare that the contract permitted it to reduce its obligation to purchase coal, it is clear that it was nevertheless willing to bear the cost of a breach, or a negotiated settlement against that breach, rather than comply fully with the contract. In North Indiana Public Service Co. v. Carbon County Co., 799 F.2d 265 (7th Cir. 1986), a utility in similar circumstances simply walked away from its long-term contract, resulting in the closure of a mine whose sole customer was that utility. See also City of Austin v. Decker Coal Co., 701 F.2d 420 (5th Cir. 1983). These cases may be as close to laboratory examples as occur in the real world. Before taking account of escalation or time-value, at roughly fifteen dollars per ton at $8,000,000$ tons a year for thirty years, the contracts had an absolute value of between three and four billion dollars, rendering litigation almost costless in comparison. Nevertheless, after stripping away the complexity of the price, delivery, and quantity obligations, the courts invoked the basic economic risk allocation issues studied in a first-year contract law course.

49. 156 Eng. Rep. 145 (1854).

50. Id. at 151 .

51. Ayres \& Gertner, supra note 23 , at 751 . The authors also conclude that there can be social welfare inefficiencies even if there is no cost to contracting around a default, particularly if there is asymmetry of information (e.g., the shipper knows how much it values prompt delivery and the carrier does not) and carrier market power. Revealing the information might prompt the carrier to take greater precautions, to contract around the default, or to charge a higher price, 
Combined with default rules for contingently incomplete contracts, changes in other variables such as asymmetry of information and the value assigned to the contract can exacerbate social welfare inefficiencies. ${ }^{52}$ Moreover, as Ayres and Gertner acknowledged, even this simple hypothetical level reveals legal and economic complexity (i.e., the number of state contingencies); "[ $t]$ he strategic inefficiencies of double-sided, asymmetric information are all the more pathological in their complexity and have only begun to be analyzed." 53

Professor Robert Scott's 2003 article studying contract indefiniteness uses empirical data to cast doubt on the regulatory power of private contractual law in complex transactions. Professor Scott concludes that complex transactions will not, as often as they will, depend on, or be significantly affected by, contractual default rules. ${ }^{54}$ He observes that first, many agreements "appear to be 'deliberately' incomplete, in the sense that parties decline to condition performance on available, verifiable measures that could be specified in the contract at relatively low cost." 55 Second, he observes that this incompleteness is more than a mere open term (like the transfer of risk of loss) in an otherwise complete and enforceable agreement; indeed, the agreement is judicially unenforceable. ${ }^{56} \mathrm{He}$ reaches the conclusion that, in fact, the better explanation is that the parties, even in transactions among relative strangers, regard those aspects of the agreement as self-enforcing:

Recent work in experimental economics suggests . . . that the domain of self-enforcing contracts may be considerably larger than has been conventionally understood. A robust result of these experiments is that a significant fraction of individuals behave as if reciprocity were an important motivation (even in isolated interactions with strangers), while a comparable fraction react as if motivated entirely by self-interest. The evidence that in any population roughly half behave fairly and half behave selfishly provides the foundation for a theory of fairness grounded in the human motiva-

whether or not the carrier is able to discriminate between high- and low-value shippers with alternative contracts. Id. at 762-63.

52. Id. at 733 (stating that "[i]n short, the introduction of even slight transaction costs will make the determination of efficient legal rules dramatically more difficult. We demonstrate that the behavior of contracting parties can change significantly in response to extremely small changes in other, more subtle underlying variables ....").

53. Id. at 765. One assumes that building an economic model of default rules around the typical sophisticated Merger and Acquisition (M\&A) agreement would be on a scale with mapping the human genome.

54. See generally Robert E. Scott, A Theory of Self-Enforcing Indefinite Agreements, 103 Colum. L. Rev. 1641 (2003).

55. Id. at 1642 .

56. Id. at $1642-43$. 
tion to reciprocate. Reciprocity requires no enforcement costs and also permits parties to contract over nonverifiable measures of performance. Thus, this theory predicts that self-enforcement of deliberately incomplete agreements between strangers is more efficient than the alternative of more complete, legally enforceable contracts. ${ }^{57}$

Scott does not pretend to explain the source of the behavior of fairness, ${ }^{58}$ but poses a number of interesting explanations for why sophisticated parties might leave a contract incomplete. 59 For purposes of this Article, I will focus only on one type, for which his hypotheses are supported by my casual empiricism: The use of legally unenforceable "comfort agreements." 60 Scott speculates that the reasons may include the parties' desire to learn something about each other's competence, market conditions, or the taste for reciprocal fairness. ${ }^{61} \mathrm{My}$ experience suggests all of the above, and I suggest another-the parties simply do not value judicial enforcement, even if they could have it. ${ }^{62}$

Finally, an entire paragraph near the end of Scott's article bears repeating in its entirety, not only for its remarkable perspicacity as to the real world, but also because of its prescience to the discussion of philosophy for working lawyers that follows:

Notwithstanding the power of reciprocal fairness, contractual breakdowns nonetheless occur, in part because as the experimental evidence suggests there is both self-interest and reciprocity in the world. But given such a world, the puzzle of indefinite contracts may

57. Id. at $1644-45$ (footnotes omitted). I contend that this is an issue fair people regularly face in dealing with unfair people. For a thoughtful treatment of the issue in negotiations, see Jonathan R. Cohen, When People Are the Means: Negotiating with Respect, 14 Geo. J. Legal ETHics 739 (2001).

58. Scott, supra note 54 , at 1675 (stating that "[w]hatever the source of that behavior (whether learned, normative, or intrinsic), it is quite relevant to understanding the contracting choices of real world individuals in developed market economies who write intentionally incomplete contracts").

59. Id. at $1675-85$.

60. Id. at $1682-83$.

61. Id.

62. There are many complex agreements that are really little more than glorified comfort agreements, for which parties expend huge amounts of money. The phrase in the practicing world for such a deal is "sign-and-close," meaning that there will not be the usual delay between the execution of a definitive agreement and the closing. At the time I am writing this, for example, we are working on a "sign-and-close" deal. By the time we close, the parties, without any enforceable contract, will have together spent hundreds of thousands of dollars in legal, accounting, Hart-Scott-Rodino (HSR) filing fees, due diligence, and other costs. Indeed, one of the reasons why a delayed closing after a definite agreement, the HSR filing, can be avoided is because the HSR Premerger Notification Rules permit a filing on a nonbinding letter of intent and an affidavit stating that the parties have "good faith" intent to complete the transaction. 16 C.F.R. $\S 803.5(a)(2)(2004)$. 
now be solved. Contracting parties simply may have learned to behave under two sets of rules: an explicit (rigid) set of rules for legal enforcement and an implicit (flexible) set of rules for self-enforcement. It may be that the lesson for courts is that any effort to judicialize preferences for fairness will destroy the very informality that makes reciprocity so effective in the first instance. The experimental evidence suggests that the contemporary academic instinct to have courts fill gaps in incomplete contracts with broadly applicable standards of reasonableness and fair treatment may actually undermine the very norms of fairness that the legal system seeks to advance. If so, it is important that neither courts nor academic commentators generalize about the impotency of reciprocal fairness from the litigated cases, as these disputes only arise when the implicit incentives have broken down. Litigated cases, therefore, give no clue of the power of reciprocal fairness in the many situations where these social preferences may have been effective in enforcing indefinite agreements, even between strangers. Understood in the broader context of a system that relies on both legal enforcement and self-enforcement, the wisdom of the common law approach becomes clearer. ${ }^{63}$

As Scott recognizes, dealmakers live with contingency, but they do not necessarily invoke the law to control it. ${ }^{64}$

Professor Manuel Utset's recent article uses economic analysis to assess how the law might address contingency in entrepreneur-venture capitalist relationships. ${ }^{65} \mathrm{He}$ makes the following observations: (1) There is a significant divergence between the expectations of entrepreneurs on one hand, and venture capitalists on the other; (2) the

63. Scott, supra note 54, at 1691-92 (emphasis added) (footnotes omitted). Cf. Lipshaw, supra note 3 , at 35 (footnotes omitted):

In the transactional world, more often than might be thought in the academic world, parties take advantage of legal principles, yet often do not take full advantage of legal rights, and their behavior is not fully a matter of risk-benefit analysis or the prediction of outcomes under well-understood legal principles. Our sense of the Golden Rule (a subset of Kant's categorical imperative) not only provides a moral basis for avoiding false promises, but keeps us, in many cases, from requiring full victory, even when we have a basis for it. Id.

64. For other interesting treatments of incompleteness, see Johnston, supra note 24 (discussing the impact of a good faith requirement on contract modification); George G. Triantis, The Efficiency of Vague Contract Terms: A Response to The Schwartz-Scott Theory of U.C.C. Article 2, 62 LA. L. Rev. 1065 (2002) (suggesting that there are economically efficient reasons why commercial parties may rationally prefer vague contract terms); Manuel A. Utset, $A$ Theory of Self-Control Problems and Incomplete Contracting: The Case of Shareholder Contracts, 2003 UTAH L. REV. 1329 (arguing that contractual incompleteness in the majority-minority shareholder context is attributable to the problem of self-control, namely procrastination); see also Douglas G. Baird et AL., Game TheORY AND tHe LAw 109-21 (1994) (applying insights of game theory to renegotiation of incomplete contracts).

65. See generally Manuel A. Utset, Reciprocal Fairness, Strategic Behavior \& Venture Survival: $A$ Theory of Venture Capital-Financed Firms, 2002 WIs. L. REV. 45. 
original venture capital contracts are incomplete (largely in the sense described in Part II); (3) the contracts generally grant most of the legal leverage to the venture capitalists; but (4) the nature of the entrepreneur's very human and very intangible contribution to the venture provides extra-contractual leverage that evens the game. ${ }^{66}$ However, the extra-legal remedy available to the entrepreneur is strategic gaming, which Utset contends leads to inefficient allocation of economic resources. ${ }^{67}$ His proposed solution-the legal imposition of a disclosure requirement from the venture capitalist to the entrepreneur-is, as he acknowledges, not nearly as robust as his analysis of the problem. ${ }^{68}$ Indeed, the underlying assumption of the entrepreneur as rational actor whose decisionmaking might be affected by better disclosure from the venture capitalist and the complexity of the situation to be modeled calls into question the efficacy of the normative recommendations. ${ }^{69}$

Another branch of the study illuminating the role of contracts in dealing with contingency is complexity. In a widely cited article, Professors Karen Eggleston, Eric Posner, and Richard Zeckhauser define complexity along three dimensions: (1) The expected number of payoff contingencies specified; (2) the variance in the magnitude of the payoffs expected to flow between the parties; and (3) the cognitive load required to understand the contract. ${ }^{70}$ They further distinguish

66. See id.

67. Id. at $53,128-46$.

68. Id. at $146-47$.

69. There appears to be something of an infinite regress inherent in a solution that is merely more information-particularly one that smacks of the typical disclaimers that go, for example, into an SEC registration statement for an initial public offering. While the investment bankers are selling, any securities lawyer worth her salt can draft disclosures and risk factors demonstrating that the business could never possibly succeed: "[A]ccordingly, there can be no assurance that management's expectations will be realized." The analog would be the venture capitalist schmoozing the entrepreneur while his lawyer gets a document with a risk factor that says: "accordingly, there can be no assurance that future conditions will not cause venture capitalist to enforce its management rights, and terminate the present officers."

Moreover, founding entrepreneurs are variously described as "over-optimistic," id. at 100-03, "over-confiden[t]" (indeed to the point of "blind[ness] ... to the need for more information"), $i d$. at 103-04, better at innovating than running a company, having "poor management skills," lacking "business savvy," Utset, supra note 65, at 92-93, and having "bounded rationality" (they cannot predict the future very well), id. at 114 n.228. In sum, the starry-eyed, cocky, sheltered engineer or scientist lacking people skills and a crystal ball is probably already overwhelmed with information. The regress is in trying to find that conclusive piece of information or disclosure that gets through to this kind of personality.

70. See generally Eggleston et al., supra note 12. The examples the authors use are contracts for architectural services, legal services, health care, software, debt, and movie stars. Id. at 94-96. These contracts are "complex" or "simple" depending on whether they combine or substitute for fixed fees with variable fees based on time, results, or specific services intended to capture relatively complex contingent results. Id. I accept the examples of complex contracts 
functionally complete contracts from functionally incomplete contracts. When a contract is functionally complete, "it performs as well as it can subject to constraints on the participants' abilities to distinguish states and the court's ability to verify which state occurred."71 Finally, they create a four-quadrant matrix to classify those contracts that are simple or complex on one axis, and those that are functionally complete or incomplete on the other. ${ }^{72}$ Noting that economists would predict highly complex contracts, but observing empirically that contracts are simpler than the degree of uncertainty, asymmetry of information, and political and regulatory environments suggest they would be, the authors attempt to explain the discrepancy. They propose several explanations, including lack of environmental complexity, negotiation costs, asymmetric information, monitoring dynamics, evolutionary pressures and forms, convention, trust and reputation, judicial enforcement costs, and bounded rationality and renegotiation. ${ }^{73}$ In short, the costs and benefits of creating complex agreements, when weighed against each other, militate toward simple agreements. ${ }^{74}$

The limits of this attempt to apply science to the complexity of state contingent agreements are apparent from the normative prescriptions. The primary thrust of this analysis is to recommend a complex scheme for the hindsight review of contracts in dispute, under which a court would attempt to divine the reasons for simplicity or complexity, and then interpret the contract strictly or liberally in accordance with the formula. ${ }^{75}$ As for working lawyers, the proponents are honest enough to recognize what, charitably, might be viewed as the early stage of their analysis. ${ }^{76}$

because as I understand it, the argument is a fortiori if applied to the complex agreements I have described above.

71. Id. at 100-02. They observe that most real world contracts are not "perfectly complete." Id. at 100 .

72. Id. at $102-03$.

73. Eggleston et al., supra note 12 , at 104-06.

74. Id. at $107-26$.

75. One can only imagine what this would look like in real world litigation over a billion dollar deal that did not work out.

76. "One normative implication of our analysis is directed to lawyers, and this is simply that more detail is not always good . . . . Complex contracts may be unnecessary when courts are sophisticated and futile when they are dull. Further research should focus on how lawyers ought to evaluate complexity when drafting contracts." Eggleston et al., supra note 12, at 126. Even in their passing reference to the implication of the approach for working lawyers, I believe they err empirically by presuming that lawyers draft contracts (even those purporting to be legally binding) with a view solely to their interpretation by disinterested third parties. See generally Scott, supra note 54. As discussed below, I believe they err even more fundamentally if they presume 
The fact is that contracts, and hence contract theory, are limited in their ability to address contingency: "All contracts are incomplete. There are infinite states of the world and the capacities of contracting parties to condition their future performance on each possible state are finite." 77 When the empirical evidence suggests parties are as influenced by self-enforcing norms as they are by contract, even in relatively simple transactions, there is a clear need to step beyond the contract to understand how and why the deal gets done.

\section{b. Strategy}

Suppose that Jones Corporation wants to sell its Widget Division. It does a discounted cash flow valuation of the business and determines that, based on its assessment of cash flows and a moderately conservative discount rate, the business is worth $\$ 500$ million. Its floor, however, is $\$ 400$ million because it needs that much cash to pursue an alternative investment, and because its CEO believes that selling the division for any less would appear to be a bad deal to the stock analysts, disproportionately impacting the value of Jones' stock.

Smith Corporation is interested in buying the Widget Division. Having reviewed the offering circular financials (but without any due diligence), Smith concludes the cash flow stream, by itself, is only worth $\$ 450$ million, but it will be able to provide cost synergies that increase the value to $\$ 550$ million. The task will be getting a deal negotiated, not only as to price, but also as to allocation of risk. Jones

that the approach for working lawyers in complex business transactions may be derived solely from a purportedly scientific model of law or economics.

Alan Schwartz and Robert Scott take a different approach to the issue of complex business contingency, although still from an ex post interpretative standpoint. They use economic analysis to demonstrate that sophisticated business firms, dealing with each other, would prefer fewer default rules based on the court's idea of fairness and more deference to the parties' choice of risk-benefit allocation. Alan Schwartz \& Robert E. Scott, Contract Theory and the Limits of Contract Law, 113 YALE L.J. 541, 608-09 (2003). They conclude, moreover, that businesses would prefer, on average, that courts attempt to divine the parties' intent, even if it were not possible in every instance. Id. at 593-94. Finally, default rules can cause inefficiencies if the parties engage in strategic behavior based on them (possible if the parties are heterogeneous, drafting costs are finite, rules are complex, the standards are exploited to redistribute surplus, and information is asymmetric). Id. at 619 .

Avery Katz's recent work has the merit of recognizing how little impact there may be in addressing issues of contract interpretation rules to judges, legislators, and other law professors, but suffers from failing to address the possibility that even private lawmakers are not writing contracts with a view to interpretation by third parties. Often, they are writing contracts, or not writing them, or leaving them ambiguous (particularly where leaving an issue ambiguous leaves one in a better position than having it clarified), or ducking issues entirely, just to get the deal done. See Avery W. Katz, The Economics of Form and Substance in Contract Interpretation, 104 Colum. L. Rev. 496 (2004).

77. Scott, supra note 54 , at 1641 . 
suspects but does not know the amount of Smith's synergy expectations, and Smith does not know that Jones' cash flow projections depend on the renewal, two years out, of several key contracts at price increases, something that is going to be difficult to achieve. Smith suspects that there is a floor amount Jones would accept but does not know what it is.

This is a strategic game with asymmetric information. The payoffs to each party range between $\$ 400$ million and $\$ 550$ million. Each is capable of "bungling." Smith could pay $\$ 550$ million for a business Jones thought was only worth $\$ 500$ million, and was willing to consider selling for as low as $\$ 400$ million. Jones could sell a business Smith thought was worth $\$ 550$ million for as little as $\$ 400$ million. ${ }^{78}$ Without attempting to solve this under game theory, I simply note the many possible slips 'twixt the theoretical cup and the real world lip. In order to predict an optimum solution, game theory holds that both parties believe the other would not select a dominated strategy (i.e., one that leads to a lesser payoff under any alternative action of the other). ${ }^{79}$ In addition, when both parties are incompletely informed, the theory requires some anticipation of how a party will change its beliefs based on the other's actions, and then select its own action consistent with that belief. ${ }^{80}$ For example, if Smith opens the bidding too high, Jones may assume that Smith thinks the business is worth more than its original valuations. ${ }^{81}$

Economic studies of strategic behavior are insightful but of relatively limited use to the dealmaker. The work points out conditions under which rational parties ought to make a deal, and at what outcome, but acknowledges the role of expectations and psychology in the process. In short, economic analysis can bring the parties to water, but it may not make them drink. This is because the empirical evidence demonstrates that human beings do not always behave as rational actors. As Utset notes, "shortly after von Neumann and Morgenstern put together their expected utility model, psychologists began to gather experimental data showing that individuals tend to violate some of the expected utility axioms." 82 The studies show that people resort to rules of thumb (heuristics) rather than algorithms,

78. BAIRD ET AL., supra note 64 , at $79-89$.

79. Id. at 80 .

80. Id. at 81 .

81. Baird and colleagues demonstrate this with an example drawn from the negotiation between Kaspar Gutman (Sydney Greenstreet) and the Russian general Kemidov over the statue in The Maltese Falcon. Id. at 81-83.

82. Utset, supra note 65 , at $68-69$. 
and "satisfice" rather than use all information available to them. ${ }^{83}$ Moreover, "[j]udgments are made against backgrounds that are at times ambiguous, uncertain, and vague, and at others, constructed and arbitrary. Our beliefs and expectations, however constructed, shape our preferences and thus shape our decisions." 84 Indeed, different disciplines-cognitive psychology, linguistics, sociology, economicseach take a different tack in analyzing the sources of our expectations. $^{85}$ Finally, game theorists warn about losing sight of games within games: "Hence, before we can be sure that a simple game captures the dynamics of a collective action problem or any other complicated interaction, we must understand the extent to which it can be isolated from the context in which it arises." 86

Economic models, even game theory, do a far better job of explaining the problem than helping the actors solve it. Economics can identify the Jones-Smith transaction as a "bargaining situation"-the interrelationship of conflict and the mutual interdependence of the parties-or a "bargaining context"-where two or more parties will negotiate to see if they can produce a surplus-but it cannot predict or even advise on how to accomplish the bargain. ${ }^{87}$ In my experience, the game theory archetypes, such as the Ultimatum Game or the Sabotage Game, ${ }^{88}$ accurately model aspects of the transaction, but offer little toward the process of getting the deal done. Dealmakers try to make deals, and doing so means confronting, often simultaneously,

83. Id. at 69.

84. Id. at 70.

85. "[O]ne's 'structure of expectations' [is] the way individuals organize knowledge about the world and use that knowledge to process new information, events, and experiences." Id. at 71. This is remarkably close to a description of what philosophy might offer, yet it is noticeably absent from most of the "scientific" literature. Our expectations are the "ought," and what we experience is the "is."

86. BAIRD ET AL., supra note 64 , at 191.

87. Utset, supra note 65 , at $72 \mathrm{n} .84$ (citing Thomas C. Schelling, The Strategy of Conflict 86-87 (1960)); see also Martin J. Osborne \& Ariel Rubenstein, Bargaining and MARKets (1990); Robert Cooter, The Cost of Coase, 11 J. Legal Stud. 1, 17 (1982); John F. Nash, Jr., The Bargaining Problem, 18 Econometrica 155 (1960). Indeed, the surplus in the Jones-Smith transaction is $\$ 150$ million, and the deal would be efficient at any negotiated price between $\$ 400$ and $\$ 550$ million dollars. Smith, the buyer, would value the business at any price up to $\$ 550$ million, and Jones would be willing to take any amount above $\$ 400$ million. Hence, if the business were sold at $\$ 500$ million, Jones would realize $\$ 100$ million of surplus (value in excess of its cost), and Smith would realize $\$ 50$ million (paying a price $\$ 50$ million less than its expected utility). This is referred to as Kaldor-Hicks efficiency. Posner, supra note 25, at 13.

88. Utset, supra note 65 , at $124-28$. As to the Ultimatum Game, I am thinking of many deals not made because a "take it or leave it" ultimatum is better than no deal, but it is still perceived by the CEO or board as unfair, and hence, not done. Alternatively, consider the Sabotage Game, where two competitors are negotiating a merger (assume it passes section 7 muster) and one is perceived to be negotiating unfairly. The aggrieved party might withdraw from the negotiation and start a price war. 
asymmetrical information, and otherwise irrational notions of fairness, fatigue, hidden agendas, opportunism, and unrealistic expectations. When everything is negotiated in the Smith and Jones deal, and at the eleventh hour, the two CEOs bicker over who will bear a $\$ 5$ million pension cost in a $\$ 500$ million deal, and their respective egos refuse to allow any concession, nothing in the economic model tells the dealmaker how to bridge that gap. ${ }^{89}$

\section{The Societal Approach}

In 1963, Professor Stewart Macaulay published a seminal analysis of the social context of contracts in business relationships. ${ }^{90}$ Like the scholars in law and economics, Macaulay sought to challenge, against empirical observations, traditional models of the impact of contract law in society. Under that model, with the decentralization of society and the transformation of society from community to organization, the legal enforcement of promises is necessary to coerce us to honor obligations to each other. In this model, the institution of contract entails careful planning of relationships, with all contingencies spelled out, a body of clear rules to facilitate planning, and the use of litigation (and the state's monopoly on force) to deter breach and resolve disputes. ${ }^{91}$ As we saw in the economic analysis of law, Macaulay sought to explain the gap between this academic model and what he observed in practice: Contract planning and law were at best marginal to most business relationships. Business people, by and large, did not care about legal contracts or honor a legal approach, and dealt with contingency by alternative mechanisms: "There are business cultures defining the risks assumed in bargains, and what should be done when things go wrong." 92 Moreover, few contract disputes are litigated, and

89. Id. at $72 \mathrm{n} .84$ (stating that "' $\mathrm{t}]$ he bargaining problem concerns how to get players in a conflict to reach an agreement that is in their mutual interest when it is in each player's individual interest to hold out for as favorable a settlement as possible.'") (quoting STEVEN J. BrAms, Negotiation Games: Applying Game Theory to Bargaining and Arbitration 29 (1990)). Non-game theory economic analysis does not purport to prescribe for individual lawyers doing particular deals. As Richard Posner notes,

The basic assumption, that human behavior is rational, seems contradicted by the experiences and observations of everyday life. The contradiction is less acute when one understands that the concept of rationality used by the economist is objective rather than subjective, so that it would not be a solecism to speak of a rational frog. POSNER, supra note 25, at 17.

90. See generally Macaulay, Non-Contractual Relations, supra note 5. Macaulay summarized the body of his work twenty-two years later in a University of Wisconsin symposium on law, private governance, and continuing relationships. See generally Macaulay, Empirical View, supra note 5 .

91. Macaulay, Empirical View, supra note 5, at 467.

92. Id. 
when they are, they are generally not resolved by the litigation itself. ${ }^{93}$ Macaulay described the various social mechanisms other than contract law that are employed to address and resolve business transaction contingency, particularly in view of the cost and uncertainty in the legal system itself: Social networks cutting across bureaucratic organizations, reputational sanctions, acquiescence to relationships of power, exploitation, and dependence. ${ }^{94}$

The law and economics movement had a goal similar to that of the law and society movement-to liberate contract law from its narrow, formal doctrinal constraints and to place it in the real world.95 Law and economics posited a set of norms dictated by one (at least theoretically measurable) utilitarian standard: The maximization of social welfare. ${ }^{96}$ Ironically, Macaulay's 1985 criticism of the limits of Willistonian doctrine could just as easily apply to much of the work, almost twenty years later, of law and economics:

The contract process in action seldom is a neutral application of abstract rationality. The party with the best argument as judged by a contracts professor will not necessarily win the case. An opponent with a plausible argument, little need to settle, and resources to play the lawyering game is unlikely to bow to arguments favored by law professors at elite schools ....

In the face of many studies challenging its descriptive accuracy, many scholars and theorists continue to paint a simple instrumental picture. What purposes are being served by all this traditional scholarly effort? Perhaps it is a form of denial. The formal contract system claims to be neutral and autonomous and to rest on simple rationality. A descriptively accurate model of the process challenges these assumptions. ${ }^{97}$

In short, Macaulay is describing the sheer complexity of the world, one with all sorts of state contingencies. Moreover, it is a world so complex that a theorist claiming to have found the single model for dealing with business contingency is either deluded by his faith in his creation or by his view of his relationship to a deity. So where do we look when we wish to channel our cross-disciplinary impulse, at least insofar as lawyers working ex ante in complex business transactions are concerned? I believe that is a philosophical question, and so it is to philosophy I turn.

93. Id. at 468 .

94. Id. at $468-71$.

95. See PosNer, supra note 25 , at $23-28$.

96. Id. at 25 (stating that "[t]he theory is that the common law is best (not perfectly) explained as a system for maximizing the wealth of society").

97. Macaulay, Empirical View, supra note 5, at 477-78. 


\section{B. The Law's Approach to Contingency in Philosophical Context}

The appropriate road to understanding how working lawyers, as counselors and advisors, might deal with commercial contingency (apart from honing their drafting skills) follows a path already paved by philosophy. Martha Nussbaum has described how law, from Langdell to Posner, has defended itself as an orderly and rational discipline through an affiliation with science. ${ }^{98}$ She observes,

Law students today very frequently learn at least some economics, since it is often claimed that this is the science (if science it is) most relevant to the understanding of the law. Far more rarely do they learn to ask questions about this whole scientific assumption and to search for alternative understandings of rigor and system. Socrates would have had some irritating questions to ask here, especially if he suspected that he was dealing with people whose confidence in their expertise outran their ability to answer questions about it. ${ }^{99}$

Having spent a career outside the ivory tower seeking to resolve contingencies on an ex ante basis, my empirical observation is that aspiring to have science fully explain how the creative process of getting deals done is, like a second marriage, the triumph of hope over experience. Such a view does not appear to have great traction outside the legal academy, and perhaps it is time to ask why. ${ }^{100}$ The disciplines of contract theory and economics have much to offer the working lawyer; ${ }^{101}$ but for the remainder of this Article, I will undertake an inquiry into how knowledge of philosophical approaches to utility, morality, and contingency might assist lawyers in the very practical business of complex mergers or bringing a fledgling enterprise into being. ${ }^{102}$

For much of human history, and. still today, people have believed there is a relationship between virtue and reward. Religion often explained why good people suffered or bad people prospered in this

98. Martha C. Nussbaum, The Use and Abuse of Philosophy in Legal Education, 45 STAN. L. REv. 1627, 1629 (1993).

99. Id. at $1629-30$.

100. See Katz, supra note 76 , at 507.

101. Although the one time I called my friend and classmate, Douglas Baird, for insights on the application of game theory to a particular problem that I was facing, he simply laughed at me.

102. Nussbaum notes:

Consider Langdell's assumption that if law is to be rational and systematic it must be a deductive hierarchy of principles. Surely it would be relevant to look at that assumption in the light of debates about method and rationality both in the philosophy of science and in moral and political philosophy. It may be that no discipline really works the way Langdell thinks science works; or, it may be that science does work this way but that law is in relevant respects unlike science. All these things need to be asked. Nussbaum, supra note 98, at 1637 (footnote omitted). 
world: They would receive the appropriate reward or punishment in the next. At the outset of the Enlightenment, the power of reason in explaining the physical world-Newton, Copernicus, Galileo-influenced some philosophers (in particular, Leibniz) to conclude that this was the best of all possible worlds. ${ }^{103}$ It would only be a matter of time until we understood all contingency - the reasons why virtue did not necessarily equate with reward. ${ }^{104}$ But that optimism diminished in the face of the cruel reality of the world, and Rousseau's great contribution was to separate the notions of natural and moral evil:105 "We are the authors of our own suffering and could be the source of our own happiness-not because God is keeping score and meting out justice, but because He has so arranged the world that such justice is part of a natural order."106

But to understand contemporary skepticism as applied to law (argued most passionately, if not most persuasively, by Judge Posner), and its rejection of idealism, and to prepare lawyers to argue with its premises, one must understand that there is nothing new under the sun. The contemporary skeptics are not the first social philosophers to reject any notion of the metaphysical or the transcendental as explanation for how we deal with the world. The great thinkers of the Enlightenment pondered and debated the contingencies and uncertainties of the world-why things do not turn out as they should-and that inquiry continues to the present day. ${ }^{107}$ Immanuel Kant argued

103. Or as Alexander Pope's Essay on Man described it poetically:

All Nature is but Art unknown to thee;

All chance direction, which thou canst not see;

All discord, harmony not understood;

All partial evil, universal good:

And spite of Pride, in erring Reason's spite,

One truth is clear, Whatever is, is right.

Alexander Pope, Essay on Man, available at http://www.theotherpages.org/poems/pope-e1.html (last visited Feb. 14, 2005).

104. Neiman, supra note 1 , at $18-31$.

105. "Recall Rousseau's project. The idea of radically separating natural from moral evil, and calling whatever is left over the human condition, was part of a search to show that events like earthquakes were events without meaning." Id. at 235.

106. Id. at 47.

107. As Susan Neiman observed,

The fact that the world contains neither justice nor meaning threatens our ability both to act in the world and to understand it. The demand that the world be intelligible is a demand of practical and theoretical reason, the ground of thought that philosophy is called to provide. The question of whether this is an ethical or metaphysical problem is as unimportant as it is undecidable, for in some moments it's hard to view as a philosophical problem at all. Stated with the right degree of generality, it is but unhappy description: this is our world. If that isn't even a question, no wonder philosophy has been unable to give it an answer. Yet for most of its history, philosophy has been moved to try.... 
there was a permanent irresolvable contingency to the world-a permanent divide between the way the world is and the way our reason tells us the world ought to be. Hegel refused to concede the gap: "The sole aim of philosophical inquiry is to eliminate the contingent." 108 Further, David Hume rejected any role at all for philosophy in addressing the issue. Our modern debates about contingency are shaped by the philosophers' speculations. ${ }^{109}$

Before we reject idealism based in philosophy as something to be valued in a working deal lawyer, we owe ourselves at least the rigor of understanding the history of that skepticism and its counterarguments. The contingency debate invokes both skeptical and idealistic epistemology ${ }^{110}$ (how do we know what we know?) and skeptical and idealistic morals (how do we decide the right thing to do?). And a central issue of contingency is whether our virtue relates to our well-being (utility, reward, happiness). Whether or not they recognize it, the new skeptics are heirs to a well-established history of skepticism that is powerful for picking apart any basis for idealism but hardly proposes a way to go about one's life, either as a matter of utility or morality. ${ }^{111}$

Id. at 7 .

108. G.W.F. Hegel, Introduction to the Lectures on the Philosophy of World HisTORY 28 (H.B. Nisbet trans., 1975) (1857); see also NeIMAN, supra note 1, at 89.

109. This and what follows are the work of a lawyer delving into philosophy to make a point for lawyers and legal scholars, and is neither a professional summary of philosophical thought nor a history of philosophy.

110. Epistemology is the branch of knowledge concerned with how knowledge is derived. FLEw, supra note 4, at 109. Historically, on one pole are rationalists (Plato and Descartes) who contend that we can only know what is true through our reason. Id. Empiricists at the other pole (Locke and Hume) contend that we only know what is true from the experience of our senses. Id.

Understanding the difference requires understanding something about the truth-value of propositions: (1) necessary propositions (those which cannot be negated); (2) contingent propositions (those which may be true, but could otherwise have been false); (3) a priori propositions (those whose truth can be established through reason alone and without reference to experience); (4) a posteriori propositions (those whose truth can only be established by experience); (5) analytic propositions (those whose truth may be established by definition); and (6) synthetic propositions (all propositions that are not analytic). Roger SCRUTON, Modern Philosophy 158-59 (1995). The statement, "a bachelor is unmarried," is analytic-it is true by definition. The proposition, "all bachelors are unhappy," is synthetic and contingent-it is not true merely by reference to the concepts within it, and even if true, might otherwise be false. $l d$. at 159 .

An empiricist would reject the notion that that there can be synthetic a priori truth. Those truths that are not true by definition may only be established as true by experience. Kant contended otherwise, and his Critique of Pure Reason set forth the argument why, and to what extent, truth could be synthetic and a priori-i.e., derived purely by our reason, as opposed to our sensory experience. Id. at 159-62.

111. This is hardly new for skepticism. As Susan Neiman observes of the great skeptics Pierre Bayle and David Hume, "[b]oth were more interested in undermining everyone else's conclusion than in establishing any of their own." Neiman, supra note 1, at 167. 


\section{Precursors of the Present Philosophical Debate}

\section{a. The Skepticism of Hume}

The natural religion of the Enlightenment was based on what is known as the "argument from design."112 It is an a priori argument that the order we see in the universe must be the product of some intelligent design - that is, God's creation of a universe containing physical and moral laws, but in which God does not intervene on a daily basis. ${ }^{113}$ David Hume's skepticism punctured the faith underlying that argument. ${ }^{114} \mathrm{He}$ rejected any role for reason in our understanding of the world or the determination of our moral obligations. ${ }^{115}$ His was a powerful denunciation of idealism. He offered neither epistemological explanation for contingency, nor a systematic ethic. Because Hume found nothing beyond the world we experience, he believed that our activities can only be directed to utility. ${ }^{116}$ His moral advice reduced in the end to a "mediocre" pragmatism. ${ }^{117}$

Hume's goal was to approach the workings of the mind and economics as the science of the Enlightenment had approached the workings of the physical world:

But may we not hope, that philosophy, if cultivated with care, and encouraged by the attention of the public, may carry its researches still farther, and discover, at least in some degree, the secret springs and principles, by which the human mind is actuated in its operations? Astronomers had long contented themselves with proving, from the phenomena, the true motions, order, and magnitude of the heavenly bodies: Till a philosopher [Newton], at last arose, who seems, from the happiest reasoning, to have also determined the laws and forces, by which the revolutions of the planets are governed and directed. The like has been performed with regard to other parts of nature. And there is no reason to despair of equal

112. See SCRUTON, supra note 110 , at 131-34.

113. A.N. WILSON, God's Funeral 22 (1999).

114. See id. at 23-26. Martha Nussbaum has preceded me in drawing parallels between the analytical styles of Richard Posner and David Hume. See Martha C. Nussbaum, "Only Grey Matter"? Richard Posner's Cost-Benefit Analysis of Sex, 59 U. CHI. L. REv. 1689, 1705-07 (1992); see generally Martha C. Nussbaum, Still Worthy of Praise, 111 HARv. L. Rev. 1776 (1998) [hereinafter Nussbaum, Still Worthy].

115. NeIMAN, supra note 1 , at $154-55,167-68$.

116. Susan Neiman describes Hume's view: " $[\mathrm{H}]$ is very reasonable explication of the circumstances giving rise to the world's evils showed that human reason leads you wrong. If you follow human reason, you expect the world to be one way. If you open your eyes, you see that it's another." Id. at 167.

117. "For those wishing to get about with a measure of safety ... which instrument [experience or reason] recommends itself? The customs and habits that guided generations of mediocre but tolerable lives before you, or a compass that, fixed on an unknown object, always seems to indicate the wrong direction?" Id. at 167-68. 
success in our enquiries concerning the mental powers and economy, if prosecuted with equal capacity and caution. ${ }^{118}$

Or as he stated in the introduction to his Treatise of Human Nature:

And tho' we must endeavour to render all our principles as universal as possible, by tracing up our experiments to the utmost, and explaining all effects from the simplest and fewest causes, 'tis still certain we cannot go beyond experience; and any hypothesis, that pretends to discover the ultimate original qualities of human nature, ought at first to be rejected as presumptuous and chimerical. ${ }^{119}$

Hume's attack on the value of moral philosophy in addressing the issues of mind and economy is unparalleled in sheer eloquence:

But this obscurity in the profound and abstract philosophy, is objected to, not only as painful and fatiguing, but as the inevitable source of uncertainty and error. Here indeed lies the justest and most plausible objection against a considerable part of metaphysics, that they are not properly a science; but arise either from the fruitless efforts of human vanity, which would penetrate into subjects utterly unaccessible to the understanding, or from the craft of popular superstitions, which, being unable to defend themselves on fair ground, raise these entangling brambles to cover and protect their weakness. Chased from the open country, these robbers fly into the forest, and lie in wait to break in upon every unguarded avenue of the mind, and overwhelm it with religious fears and prejudices. ${ }^{120}$

How then did Hume address the issue of contingency, either epistemologically or morally? From an epistemological standpoint, Hume concluded that reason-our ideas or our ideals-has no bearing on, or utility in, making sense of the world. Ideas are simply copies of our sense impressions. ${ }^{121}$ We can tell the difference between an idea and an experience because of its clarity: There is a difference between having the idea of my son and seeing my son. The latter is sharp and distinct relative to the former. What we know from ideas has no implications for what we experience. What we presume to know in the physical world is a presumption of cause and effect, not provable by reason, derived from the constant conjunction of certain causes and certain effects. We have never seen a billiard ball fail to move when struck by another one, so we infer the first ball striking the second caused it to move. There is no reason in logic why the second ball must move: We can imagine a world in which, having been struck, the second ball remains stationary or disappears in a puff of smoke.

118. David Hume, an Enouiry Concerning Human Understanding 8 (1993) (1777).

119. David Hume, A Treatise on Human Nature 44 (Ernest C. Mossner ed., 1985) (1739).

120. Hume, supra note 118 , at 5-6.

121. David Hume, An Abstract of a Book Lately Published, Entitled, A Treatise of Human Nature, \&C., excerpted in The Philosopher's HANDbook 441 (Stanley Rosen ed., 2000). 
So what is our basis for being able to predict that the sun will rise again, or the car will start when I turn the key? Hume's answer is psychological disposition-"custom" or "habit."122 Our reliance on the continued consistency of experience is a kind of natural instinct. And do we have free will, or are we subject to determinacy? Hume finds the distinction empty: Only experience, and not reason, ties actions to morality, just like the cause and effect of physical events. ${ }^{123}$ We experience the same repeated conjunctions of apparent cause and effect, and expect the future will resemble the past. What we sense as freedom is simply the absence of an external restraint. Our choices are equally determined, but we assume, merely from the continued observation of the impact of choice and its outcome, what is moral and what is not. ${ }^{124}$

But to understand Hume's view of morality, we need to further analyze the last two sentences. If reason finds morality in the linkage of the exercise of virtue with material reward, then it is as specious as any other attempt to know anything other than by experience. In this regard, he took on the optimistic general Providence of deism: That the designs of nature prove the infinite goodness of its cause. ${ }^{125}$ To prove that the world is not what our reason would expect it ought to be if designed or operated by a good God, one need only observe the miseries, pains, and uncertainties of life. He concludes that

[t] here may four hypotheses be framed concerning the first causes of the universe: that they are endowed with perfect goodness, that they have perfect malice, that they are opposite and have both goodness and malice, that they have neither goodness nor malice. Mixed phenomena [the fact we observe both good and evil] can never prove the two former unmixed principles. And the uniformity and steadiness of general laws seem to oppose the third. The fourth, therefore, seems by far the most probable. ${ }^{126}$

In the face of the randomness of good and evil as proved by experience, why be moral? As one would expect, his view of morality is that, like truth, it should be determined on the basis of experimental

122. Id. at 444 .

123. Id. at $450-51$.

124. Hume said,

And as there is often a constant conjunction of the actions of the will with their motives, so the inference from the one to the other is often as certain as any reasoning concerning bodies: and there is always an inference proportioned to the constancy of the conjunction. On this is founded our belief in witnesses, our credit in history, and indeed all kinds of moral evidence, and almost the whole conduct of life.

Id. at 451 .

125. See generally David Hume, Dialogues Concerning Natural Religion (Martin Bell ed., 1990) (1779).

126. Id. at 122 . 
method, not reasoned speculation. ${ }^{127}$ Hume observes that moral judgments are regularly accompanied by a sense of approval or disapproval that precedes the judgment. ${ }^{128}$ Hume concludes that the only common element of our sense of approval or disapproval of particular actions is utility. ${ }^{129}$ Benevolence, justice, and government only occur and are generally acknowledged to be virtuous when they have utility for us. ${ }^{130}$ None of this is the result of a priori knowledge, nor are the qualities restricted to those who happen to possess greater powers of reason:

The social virtues must, therefore, be allowed to have a natural beauty and amiableness, which, at first, antecedent to all precept or education, recommends them to the esteem of uninstructed mankind, and engages their affections. And as the public utility of these virtues is the chief circumstance, whence they derive their merit, it follows, that the end, which they have a tendency to promote, must be some way agreeable to us, and take hold of some natural affection. It must please, either from considerations of self-interest, or from more generous motives and regards. ${ }^{131}$

In the end, according to Hume, there is no ideal by which to set one's course in life, except to rely on our common sense and live pragmatically:

And, in general, no course of life has such safety (for happiness is not to be dreamed of) as the temperate and moderate, which maintains, as far as possible, a mediocrity, and a kind of insensibility, in every thing. ${ }^{132}$

Hume's empirical emphasis on utility influenced his friend Adam Smith and the later utilitarians like Jeremy Bentham and John Stuart Mill. ${ }^{133}$

\section{b. The Limited Idealism of Kant}

Kant sought to find a middle ground between the sharp skepticism of Hume and the pure idealism of Leibniz. In his Critique of Pure Reason, Kant argued that synthetic a priori knowledge-knowledge

127. David Hume, An Enouiry Concerning the Principles of Morals 9 (Eugene Freeman ed., 1966) (1777).

128. See id. at $65-67$.

129. "In general, what praise is implied in the simple epithet useful! What reproach in the contrary!" Id. at 12.

130. See id. at 8-45.

131. Id. at $48-49$.

132. Neiman, supra note 1 , at 166 (quoting David Hume, Dialogues Concerning Natu. ral Religion 184 (J.C.A. Gaskin ed., 1993)).

133. See generally John Stuart Mill, Utilitarianism (1861), excerpted in Philosophy: Basic Readings 99-103 (Nigel Warburton ed., 1999); Jack Russell Weinstein, ON Adam Smith (2001); Adam Smith, The Theory of Moral Sentiments (2000) (1854). 
accessible to us only through reason and not experience-was possible. ${ }^{134}$ Indeed, his argument was that such a priori knowledge was necessary even for a skeptic like Hume to pose the question "how do we know?"135 But Kant reached a surprisingly nuanced conclusion: The only things we can judge to be true are those which, in the first instance, are the subjects of our experience (or possible experience). ${ }^{136}$ The way we perceive that experience is shaped by certain concepts, which together constitute our understanding that we simply could not have acquired from experience, such as unity, causation, substance, and plurality. ${ }^{137}$ In short, in the first part of the Critique of Pure Reason, Kant deduces that, subjectively, we are able to order and explain our experience only with an already ingrained take on the world. Moreover, he deduces that there is objective knowledge: We observe a world that can be other than it seems to us, and which exists independently of our perspective on it. ${ }^{138}$ Kant rejects the pure idealistic notion that everything happens for a reason-that there is either a specific or a general Providence knowable to us objectively. ${ }^{139}$ But in the world of experience, there is an objective law of causality. As to empirical events in time and space, everything that happens is bound by cause and effect. ${ }^{140}$

Kant's application of his metaphysics to morality is important to understand in responding to the skeptical view and is the subject of his Critique of Practical Reason. ${ }^{141}$ Kant's basic metaphysical distinction is that in practical matters, reason is capable of letting us decide what we ought to do-it makes no claims as to truth or falsity. ${ }^{142}$ As to the assessment of truth, reason that takes us beyond experience or possible experience is "pure." 143 It seeks unconditioned knowledge of the world-to view the world from a point of view other than that of the observer. ${ }^{144}$ And pure reason, detached from experience or possible experience, can make no claims of truth about the objective world. ${ }^{145}$

134. See generally Immanuel Kant, Selections from Critique of Pure Reason, in Basic Writ. INGS OF KANT, supra note 13 at 1.

135. See id. at $35-38$.

136. Id. at 3 .

137. Kant called these "categories." Id. at 57-59.

138. Id. at $60-87$.

139. Id. at 19.

140. KANT, supra note 13 , at $82-83$.

141. See generally Immanuel Kant, Selections from Critique of Practical Reason 223, in BASIC WRITINGS OF KANT, supra note 13.

142. Id. at 225-26.

143. KANT, supra note 134 , at 6 .

144. Id. at 13-14.

145. See id. 
As to morality, Kant rejects the notion that we are merely slaves to the cause and effect of the physical world, and the basis of this rejection is the role of our reason in helping us determine what we ought to do. ${ }^{146}$ We are physical beings subject to the natural world of cause and effect, of hunger and desire, of greed and fear, and at the same time, we are free and autonomous moral agents with the power to will an end, whether or not it is in our self-interest. ${ }^{147}$ As one writer describes it:

Of all [intentional] actions the question can be asked: Why do that? This question asks not for a cause or explanation, but for a reason. Suppose someone asks me why I struck an old man in the street. The answer 'Because electrical impulses from my brain precipitated muscular contractions, and this resulted in my hand making contact with his head' would be absurd and impertinent, however accurate as a causal explanation. The answer 'Because he annoyed me' may be inadequate in that it gives no good reason, but it is certainly not absurd. Reasons are designed to justify action, and not primarily to explain it. They refer to the grounds of an action, the premises from which an agent may conclude what to do. ${ }^{148}$

This is no mere historical point. There is, in relatively recent scholarly literature on contract default rules, a debate that arises out of confusion over this very issue. Professor Charles Fried is an heir to Kant when he characterizes contract as a subset of promise, and sees its moral basis in our power, by our will, to intervene in and change the course of the world of cause and effect. ${ }^{149}$ Fried uses practical reason to access a moral law we should accept universally-we honor our promises: "The obligation to keep a promise is grounded not in arguments of utility but in respect for individual autonomy and in trust." 150

In his oft-cited criticism of Fried's autonomy theory, Richard Craswell argues that the moral basis for promising does not provide any coherent basis for determining how to resolve incompleteness issues with default rules. ${ }^{151}$ Without my expressing a view on whether Fried

146. KANT, supra note 13 , at 203.

147. "The positive concept of freedom furnishes this . . cognition, which cannot, as with physical causes, be the nature of the sensible world (in the concept of which we find conjoined the concept of something in relation as cause to something else as effect)." Id. at 204.

148. Roger Scruton, Kant, in German Philosophers 1, 69-70 (Keith Thomas ed., 1997).

149. Charles Fried, Contract as Promise 7-8 (1981). For another view on why we consider the law to bind us, see Rex J. Zedalis, On First Considering Whether Law Binds, 69 IND. L.J. 137 (1993).

150. FRIED, supra note 149 , at 16.

151. Richard Craswell, Contract Law, Default Rules, and the Philosophy of Promising, 88 Mich. L. Rev. 489, 517-24 (1989). 
or Craswell has the better of it on default rules, ${ }^{152}$ there is little question that Fried has a better handle on the philosophical context-harmonizing both the moral and utilitarian aspects in Kantian fashion:

There is ... a version of rule-utilitarianism that makes a great deal of sense. In this version the utilitarian does not instruct us what our individual moral obligations are but rather instructs legislators what the best rules are. If legislation is our focus, then the contradictions of rule-utilitarianism do not arise, since we are instructing those whose decisions can only take the form of issuing rules. From that perspective there is obvious utility to rules establishing and enforcing promissory obligations. Since I am concerned now with the question of individual obligation, that is, moral obligation, this legislative perspective on the argument is not available to me. ${ }^{153}$

The frustration with accepting Kant's enduring dualism between the transcendental "ought" and the real world "is," captured in the exchange between Fried and Craswell, is the basis for much of the philosophy that followed Kant. Some, expressed most thoroughly and vividly by Hegel, took the view that there was no dualism and hence, no contingency; there was an "ought" and the history of the world was the progress toward the unity of the "is" with the "ought."154 For others, there was pragmatism.

\section{Pragmatism}

Pragmatism is a classification under which falls the thinking of a number of influential American thinkers spanning the turn of the twentieth century-William James, John Dewey, Charles Peirce, and Justice Holmes-as well as contemporary thinkers such as Richard Rorty. It responds to the gap between the "is" and the "ought" by concluding it is a problem beyond our ability to solve. Although it is

152. Indeed, the point of this Article is that the role of courts or legislatures in setting default rules is of more concern in scholarly debates among law professors than it in in the world of deal lawyers. Nevertheless, I have argued elsewhere that contracts qua contracts are not moral instruments. Jeffrey M. Lipshaw, Duty and Consequence: A Non-Conflating Theory of Promise and Contract, available at http://ssrn.com/abstract=664611 (last visited Mar. 11, 2005).

153. FRIED, supra note 149 , at 16 . For what it is worth, Kant would have probably opted for formalism over substance in the interpretation of contracts, consistent with his view that the practical world should consist of positive law. See Jeremy Waldron, Kant's Legal Positivism, 109 HARV. L. REV. 1535, 1545 (1996). Waldron states:

The premise of Kant's account is that, in the absence of legal authority, we must expect that individuals will disagree about right and justice and that this disagreement will lead to violent conflict. The task of the legislator is to put an end to this conflict by replacing individual judgments with the authoritative determinations of positive law.

Id. at 1545 .

154. The philosophy of Hegel is not directly relevant to my thesis, and I leave it for professional historians of philosophy. See Neiman, supra note 1, at 84-103; Peter Singer, Hegel, in German Philosophers, supra note 147, at 105. 
difficult to capture all of the variants of pragmatic thought in a few sentences, common denominators are beliefs that: (1) Ideas do not necessarily reflect the world as it is; ${ }^{155}$ (2) the truth-value of an idea (i.e., whether it accurately describes the world) is not necessarily related to the utility of the idea; ${ }^{156}$ and (3) the dogmatic insistence on the truth of any single idea, particularly in the face of experience, is wrong. ${ }^{157}$ As William James wrote:

A pragmatist turns his back resolutely and once for all upon a lot of inveterate habits dear to professional philosophers. He turns away from abstraction and insufficiency, from verbal solutions, from bad a priori reasons, from fixed principles, closed systems, and pretended absolutes and origins. He turns toward concreteness and adequacy, towards facts, towards action and towards power. That means the empiricist temper regnant and the rationalist temper sincerely given up. It means the open air and possibilities of nature, as against dogma, artificiality, and the pretence of finality in truth. ${ }^{158}$

Like philosophers before them, the pragmatic thinkers wrestled with the issue of contingency. John Dewey described the world as fearful, awful, precarious, and perilous. ${ }^{159} \mathrm{He}$ further wrote, "The striving to make stability of meaning prevail over the instability of events is the main task of intelligent human effort."160 But Dewey saw the resolution of contingencies not in philosophical speculation, but in the work of science:

[T] he things of ordinary experience contain within themselves a mixture of the perilous and uncertain with the settled and uniform. The need for security compels men to fasten upon the regular in order to minimize and to control the precarious and fluctuating. In actual experience this is a practical enterprise, made possible by knowledge of the recurrent and stable, of facts and laws. Philosophies have too often tried to forego the actual work that is involved in penetrating the true nature of experience, by setting up a purely theoretical security and certainty. The influence of this attempt upon the traditional philosophic preference for unity, permanence,

155. Richard Rorty, Contingency, Irony ANd Solidarity 4-5 (1989). Rorty argues: We need to make a distinction between the claim that the world is out there and the claim that the truth is out there. To say that the world is out there, that it is not our creation, is to say, with common sense, that most things in space and time are the effects of causes which do not include human mental states. To say that truth is not out there is simply to say that where there are no sentences there is no truth, that sentences Id. are elements of human languages, and that human languages are human creations.

156. Menand, supra note 11 , at 356.

157. William James, What Pragmatism Means, in The Writings of William James 379 (John J. McDermott ed., 1977).

158. Id.

159. Dewey, supra note 2, at 42.

160. Id. at 50 . 
universals, over plurality, change and particulars is pointed out, as well as its effect in creating the traditional notion of substance, now undermined by physical science. ${ }^{161}$

How did (and does) pragmatism suggest we deal with issues of contingency and morality? What is clear is it is not by an appeal to any kind of idealism. The essence of pragmatism is its lack of adherence to any particular dogma; we can characterize it as a philosophy under which you do whatever works to accomplish the end you want to accomplish. Like his philosophical predecessors, Dewey linked his epistemology to his moral theory. ${ }^{162}$ Getting wrapped up in whether an idea corresponds to the reality of existence is a waste of time. Better

161. Id. at iii-iv. This passage, written in 1929, speaks volumes about Dewey's linkage of Kant and Hegel to the scientific discoveries of the early twentieth century. Dewey studied Kant and Hegel at Johns Hopkins, and was particularly influenced by Hegel's philosophy of history. Menand, supra note 11, at 261-72. Dewey could be characterized as

a serious person, too. He wasn't interested in philosophy as a form of mental exercise. He was interested in it as a guide to living, and Hegel turned out to be just what he was looking for. Hegel's philosophy made a much closer corollary to Huxley's picture of the body as an integrated organism than Torrey's attenuated Kantianism had. Id. at 266.

Dewey is thus clearly referring to Hegel's "elimination of the contingent" when he describes philosophies of theoretical security and certainty. See DEwEY, supra note 2, at 50. It would also appear that he is referring to Kant, particularly as to substance, which Kant includes as one of the a priori categories by which our minds organize the world. KANT, supra note 134, at 59. Moreover, there can be little doubt about the notions of substance being undermined by physical science at the time. Max Planck first proposed quantum theory in 1900. Timothy Ferris, CoMING OF AGE IN THE MILKY WAy 286 (1988). In 1927, Werner Heisenberg announced the indeterminacy principle, that the very act of observing makes it so we can either know the positon of a particle or its trajectory, but not both. Id. Quantum physics undermined the very cause and effect at the heart of classical physics:

Classical physics was deterministic: If $\mathrm{A}$, then $\mathrm{B}$; the bullet fired at the window shatters the glass. On the quantum scale this is only probably true: Most of the particles in the bullet encounter those of the glass, but some go elsewhere, and the trajectory of any one of them can be predicted only by invoking the statistics of probabilities. Einstein was deeply troubled by this aspect of the new physics. "God does not play dice," he said, and he argued that the indeterminacy principle, though useful in practice, does not represent the fundamental relationship between mind and nature.

$I d$. at 290 . In short, science was undermining not just prior science, but the a priori assumptions of philosophers on matters as basic as substance and causation. No wonder, then, that Dewey, writing in 1929, might be inclined to reject philosophic speculation about the fundamental nature of the world in favor of a pragmatic thought.

162. Dewey stated:

The facts of the ungoing, unfinished and ambiguously potential world give point and poignancy to the search for absolutes and finalities. Then when philosophers have hit in reflection upon a thing which is stably good in quality and hence worthy of persistent and continued choice, they hesitate, and withdraw from the effort and struggle that choice demands:-namely, from the effort to give it some such stability in observed existence as it possesses in quality when thought of. Thus it becomes a refuge, an asylum for contemplation, or a theme for dialectical elaboration, instead of an ideal to inspire and guide conduct.

DEWEY, supra note 2, at 53 . 
to avoid the dangers of philosophic contemplation of truth (with its inherent tendency to find absolutes and extremes), and simply act in this world to make things better. ${ }^{163}$ Approaching contingency solely through reason explains but does no more; its ultimate expression is superstition or religion. ${ }^{164}$ Compared to the subjective musings of philosophy, the inquiries of science, which reach objectively into nature, are better "because reached by method which controls them and which adds greater control to life itself, method which mitigates accident, turns contingency to account, and releases thought and other forms of endeavor." 165

In 1891, James spoke similarly of the role of idealistic philosophy to morals:

[Intuitional or idealist thinkers] deserve credit for keeping most clearly to the psychological facts. They do much to spoil this merit on the whole, however, by mixing it with that dogmatic temper which, by absolute distinctions and unconditional 'thou shalt nots,' changes a growing, elastic, and continuous life into a superstitious system of relics and dead bones. ... There is but one unconditional commandment, which is that we should seek incessantly, with fear and trembling, so to vote and act as to bring about the very largest total universe of good which we can see. ${ }^{166}$

163. See id. at 52-77.

164. Id. at 52 (stating that "[t]he consequence [of pure metaphysics] is that conversion of unavowed morals or wisdom into cosmology, and into a metaphysics of nature, which was termed in the last chapter the philosophic fallacy").

165. Id at 70 . This same point served as the basis for Dewey's educational philosophy:

[T] he difference in abstract principles will not decide the way in which the moral and intellectual preference involved shall be worked out in practice .... I take it that the fundamental unity of the newer philosophy is found in the idea that there is an intimate and necessary relation between the processes of actual experience and education.

John Dewey, EXPERIEnCE ANd Education 20 (1997) (1938).

166. William James, The Moral Philosopher and the Moral Life, in The Writings of WILLIAM JAMES, supra note 157 , at 625-26. As noted in MENAND, supra note 11 and accompanying text, James viewed the question of whether a particular belief was justified as one distinct from whether it was true. Among those characterized as pragmatists, there is a wide divergence of views on the utility of beliefs. Richard Rorty, for example, argues that our beliefs are the product of our language and culture, and hence themselves are contingent on changes in language and culture from one period to the next. See RorTy, supra note 155 . Hence, he claims that the recognition of that contingency is the chief virtue of a liberal society in which metaphysical needs have disappeared. Id. Compare this to Dewey's view of the role of ideals in experience, quoted partially as the introduction to the Article:

A particular ideal may be an illusion, but having ideals is no illusion. It embodies features of existence. Although imagination is often fantastic it is also an organ of nature; for it is the appropriate phase of indeterminate events moving toward eventualities that are now but possibilities. A purely stable world permits of no illusions, but neither is it clothed with ideals. It just exists. To be good is to be better than; and there can be no better except where there is shock and discord combined with enough assured order to make attainment of harmony possible.

DEWEY, supra note 2, at 62 . 
With this brief grounding in the philosophy of utility, morality, and contingency, we turn finally to its expression in the current literature of the law and how it might impact the lawyer working ex ante to get deals done.

\section{A Philosophy of Contingency For the Deal Lawyer}

\section{A. The Mix of Contractual and Non-Contractual Contingencies in Complex Transactions}

In Part II.A, I touched on the sheer complexity of contracts used in complex business transactions. I concur, however, with the sociological observations that the role of the law in such transactions is hardly as central as either the lawyers or legal scholars might presume it to be. It would be disingenuous to suggest that the power of the state to enforce adjudicated contract rights has no consequence. But contracts create moral markers as much as legal rights and duties. The real world of M\&A work or the creation of a high technology business cannot be modeled by solely legal or even economic rules. There is too much contingency and too broad a range of conceivable outcomes. For the uninitiated, what follows is a brief and anecdotal sense of the non-legal contingencies, those not addressed by traditional law and economics models of contract, faced by participants (including lawyers) in those worlds. ${ }^{167}$

\section{Contingency in Mergers and Acquisitions}

The deal that resulted in the famous Texaco-Pennzoil litigation not only demonstrates the matrix of legal and non-legal contingency that

167. I focus on these two areas because they are the ones with which I have the most experience. Lisa Bernstein has studied a series of other complex and close-knit business communities, focusing on the legal and extra-legal norms by which they deal with the contingencies of their businesses. See, e.g., Lisa Bernstein, Opting Out of the Legal System: Extra-Contractual Relations in the Diamond Industry, 21 J. Legal Stud. 115 (1992).

The complexity of the role of extra-legal norms, including the so-called incommensurability thesis, has long been the subject of debate among legal scholars. Professor Sunstein wrote the seminal work, arguing that there is a theory of choice among a range of incommensurable values and options that can account for people's social behavior. See generally Cass R. Sunstein, Incommensurability and Valuation in Law, $92 \mathrm{MiCH}$. L. Rev. 779 (1994). Eric Posner argues, on the other hand, that we may observe what looks like incommensurability, but it is a mistake to assume that this is based on values, as opposed to rational calculation of economic or reputational gain. PosNer, supra note 5, at 185-202. Posner takes a game theoretical approach to nonlegal norms, arguing that being perceived by others as a good type is instrumental-it furthers our interests-and a good type, in the course of the game, engages in "signaling" to the other players that he or she is in fact a good type. $I d$. at $18-27$. I obviously weigh in on the Sunstein side of the debate, and I believe that the anecdotes in the next section provide at least some support for that argument. 
acquisitions lawyers and dealmakers face, but also the danger of thinking about contingency only as a lawyer might. Texaco acquired Getty Oil in 1983. Two years later, a state court jury in Houston awarded Pennzoil, the outbid suitor, breach of contract damages in excess of $\$ 7$ billion and punitive damages in excess of $\$ 3$ billion on a contract that had never been signed.168

In the early 1980s, effective control of Getty Oil, a public company, resided in two parties: Gordon Getty, the intellectual son of J. Paul Getty, and the board of trustees of the J. Paul Getty Museum. ${ }^{169}$ Through family trusts, Getty controlled forty percent, and the museum owned twelve percent of the common stock of Getty Oil. ${ }^{170}$ Without getting into the myriad details of motivating factors, ${ }^{171}$ over the several days following New Year's Day 1983, Getty Oil was on the brink of being sold to Pennzoil. ${ }^{172}$

The negotiations culminated in a twenty-five hour session on January 3 and 4, 1983. Liedtke had offered $\$ 100$ per share for Getty Oil, and, unknown to the Getty Oil board, had privately executed a short memorandum of agreement with Gordon Getty for his support of the sale at that price, and his commitment to urge the museum to do the same. ${ }^{173}$ In exchange, Getty would be the chairman of the merged company. ${ }^{174}$ The museum, represented by Lipton, separately negotiated an additional $\$ 10$ per share. ${ }^{175}$ All of this was presented to the Getty Oil board of directors, most of whom believed the company was undervalued at either $\$ 100$ or $\$ 110$, with a time limit under which the offer would be withdrawn if not accepted before the board meeting was adjourned. ${ }^{176}$

168. See Thomas Petzinger, Jr., Oil and Honor: The Texaco-Pennzoll Wars (1987). This may be the single best book about deals and litigation I have ever read. Its size, fact situation, and outcome are pathological, but almost every deal lawyer can identify with the whirl of events, adrenaline rush, and confusion. All litigators should read the first half to understand the dynamics of dealmaking, and all transactional lawyers should read the second half to understand how what they do, legally and non-legally, can be perceived by ordinary people.

169. Id. at 88 .

170. Id.

171. See id. at 13-154 (e.g., the dysfunctional Getty family, Gordon Getty's unsuitability to run the company, the "eat or be eaten" acquisition craze in the oil business in the early 1980s, the mercurial and acquisitive chairman of Pennzoil, Hugh "Chairman Mao" Liedtke).

172. Id. at 158 .

173. Petzinger, supra note 168 , at 161 .

174. Id.

175. Id.

176. Petzinger recorded the director's reaction to the offer and the deadline as follows:

This is blackmail! many of the directors thought.

Henry Wendt [a director] was convinced that Gordon was selling the public shareholders down the river simply to achieve a long-coveted ambition to become chairman 
During the meeting, the Getty board pressured Getty to negotiate an additional $\$ 10$ to bring the price to $\$ 120$ per share, arguing that although Salomon Brothers may have assured the museum $\$ 110$ was fair (on only two days' study), Goldman Sachs had not done the same for the public shareholders, whom the Getty board represented. ${ }^{177}$ Only then did Gordon Getty reveal his private agreement with Liedtke, and there was rancorous fallout among the directors. ${ }^{178}$ As the board meeting continued through the early morning hours, Lipton, representing the museum and sensing that the deal was falling apart, suggested to the Getty Oil board that it consider going back to Pennzoil with a creative structure of cash and debentures valued at $\$ 120 .{ }^{179}$ The Getty board approved this at 2:30 a.m., and the investment bankers prepared a handwritten letter, which was left with the Pennzoil banker at 4:30 a.m. ${ }^{180}$

The next day, before the Getty board reconvened at 3:00 p.m., Liedtke and Pennzoil's team, including its lawyer, Arthur Liman, made a complex counteroffer at either $\$ 110$ a share, or $\$ 90$ per share plus the proceeds of a spin-off of a Getty subsidiary that would be completed after the sale. ${ }^{181}$ Lipton told Liman "It won't sell . . . It's too cute." 182 Liman went back to Liedtke and secured authority to bump the value of an offer up to $\$ 111.50 .{ }^{183}$ Lipton asked Liman to make it $\$ 112.50 .{ }^{184}$ Liman said he would not go back to Liedtke with-

of the board. "Do you know what this company is worth?" he demanded. "Have you tried to shop the company?"

"I've considered and rejected many things," Gordon calmly answered. "This approach is best." Another recess, during which the finger sandwiches and little weenies came in.

Dr. Laforce of UCLA [a director] resented the whole thing. "We're being placed in a position of having to make a decision in three or four hours on a take-it-or-leave-it basis," he said. "This involves enormous sums of money and some complex issues. Why was this proposal structured to be withdrawn if it wasn't accepted right now?"

"In the terms of the trade," explained Boisi of Goldman, Sachs, "Pennzoil is using a 'bear hug.' They're using speed and pressure to get a good deal for themselves. That's the tactical reason for putting a deadline on the deal."

Id, at 174-75.

177. Id. at 177 .

178. Id. at $179-80$.

179. Petzinger, supra note 168 , at 180 .

180. Id. at $181-82$.

181. Id. at 186 .

182. Id.

183. Id. at 187.

184. Id. 
out a firm deal. ${ }^{185}$ Lipton agreed to seek the Getty board's approval. ${ }^{186}$

Liman waited while the board listened to Lipton, the lawyer for the museum and a twelve percent shareholder, present the $\$ 112.50$ offer. ${ }^{187}$ After a raucous three-hour session that pitted the Getty directors against their own investment bankers (who would not call the offer fair), the board approved a $\$ 112.50$ sale of the company by a 15-1 vote. ${ }^{188}$ Liman testified later that the "doors flew open," and he heard from either Lipton or Martin Siegel, Gordon Getty's investment banker, "Congratulations, Arthur, you've got yourself a deal."189 Whether many hands were shaken was later a matter of dispute. ${ }^{190}$

But no document was signed. In the next two days, Bruce Wasserstein, then at First Boston, contacted Lipton and eventually engineered the deal in which Texaco trumped Pennzoil and acquired Getty Oil for $\$ 125$ per share, and the litigation ensued. ${ }^{191}$

The centrality (or lack thereof) of law as the means by which contingency is addressed in a transaction, at least as perceived by nonlawyers, is evident from the account of Lipton's cross-examination (by Joe Jamail) on the question of whether he and Arthur Liman had a deal. Lipton had testified on direct examination to the effect that there could not have been a binding deal as of the conclusion of the board meeting because "in his opinion Gordon could never have completed the Pennzoil deal without hiring lawyers who specialized in complex oil-and-gas transactions." ${ }^{192}$ The following examination ensued:

"Are you saying that two people cannot agree unless they hire a bunch of lawyers to tell them they've agreed?" Jamail demanded.

"I'm not saying that at all, Mr. Jamail. I'm saying that two people who are contemplating an agreement with respect to a ten-billiondollar transaction would be awfully foolish to do it on the basis of an outline and the absence of an expert's advice ...."

Jamail knew what he wanted.

"Mr. Lipton," he said, glaring, "are you saying that you have some distinction between just us ordinary people making contracts with each other, and whether or not it's a ten-billion-dollar deal? Is there a different standard in your mind?"

185. Petzinger, supra note 168 , at 187.

186. Id.

187. Id. at 188.

188. Id. at 191.

189. Id. at 192.

190. Id. at $186-93$.

191. Petzinger, supra note 168 , at 193-234.

192. Id. at 371. 
"Yes, indeed."

"At that point," juror Jim Shannon would recall, "my jaw just dropped."

Jamail waited a full five seconds to let the response sink in.

"Oh," Jamail said. "I see."

"So if it wasn't a bunch of money involved in this Getty-Pennzoil transaction, it could be an agreement?"

"Well, if there was five or ten dollars involved, I guess you might say that."

In fact, Lipton was articulating a legal principle codified in 17th century England and known as the Statute of Frauds, which held that complex transactions of great size or complexity do impose a higher degree of agreement. But as far as the jury was concerned, Marty Lipton had just made honor in business contingent on the number of dollars involved. ${ }^{193}$

When Martin Lipton got the call from Bruce Wasserstein, he used his lawyer's model of contracts and contingency to conclude that there was no deal. ${ }^{194}$ As the jury verdict proved, the public did not necessarily agree.

James Freund, one of the great M\&A lawyers (and one of the best and most prolific theorists, raconteurs, and authors on the subject of getting deals done) described the relationship of legal and non-legal skills in negotiating a complex merger:

Unlike a work on abstract legal principles or such related practical matters as structuring a merger, as to which there are certain objective criteria for judgment, this subject often boils down simply to a matter of "feel," based on experience-as to where, for example, a particular line can and should be drawn, to compromise opposing viewpoints while adequately protecting each of the parties. Other practitioners would undoubtedly take different stands on specific matters, and needless to say, each reader is encouraged to seek his own level. There is no "right" position on, or solution to, the typical negotiating problem. To achieve workable compromises and consummate deals, you must dismiss all rigid postures from your mind

193. Id. Compare this story to the assessment of the role of the U.C.C. Statute of Frauds in a model that assumes people are rational actors, and whether judicial approaches to its application impact behaviors. See generally Eric A. Posner, Norms, Formalities and the Statute of Frauds: $A$ Comment, 144 U. PA. L. Rev. 1971 (1996). Getty Oil and Pennzoil did not have a signed writing, definitive or not, because: (1) At least one side believed its handshake was its bond; (2) the directors and lawyers were exhausted after all-night sessions; (3) the lawyers worked on documents through another all-night session after the board meeting because they were not sure what happened in the board meeting; and (4) in the flurry of the conclusion of the board meeting, nobody from Getty Oil stopped to sign the five page memorandum of understanding (albeit at the $\$ 110$ per share price) already signed by Gordon Getty and Hugh Liedtke. Petzinger, supra note 168 , at 191-99.

194. Petzinger, supra note 167, at 202. 
and roll with the punches, adapting yourself to the situation and your opposite number. ...

There is a great intermeshing of disciplines in connection with a merger negotiation. My experience is that everyone else involvedaccountants, businessmen, investment bankers-contribute ideas that could be termed "legal," while the lawyer himself is frequently pointing out considerations that could be considered "accounting" or "business" or "financial." If there is to be real teamwork, it is important that everyone concerned have an inkling of what is going on in the lawyer's mind in connection with making a deal. ${ }^{195}$

Freund's point is the same one raised in the outset of this Article, and is not a legal or economic question, but one of philosophy. How, in the face of great contingency, legal and otherwise, do we decide when to be rigid, to hold to our view of the world as it ought to be, or flexible, to conclude that the world as it is may be alright? How do we gather the psychic energy to find the creativity to bridge gaps between the parties, or do we simply accept the fact that there is a gap and go home?

\section{Contingency in Start-ups and Venture Capital}

There are massive contingencies in starting a business and funding it with venture capital financing, but almost none of them (save patent protection) are addressable by law. As Freund described for mergers, there are basic start-up structures as to which there are almost objective criteria, involving the ratio of the funds invested to fully diluted equity position in convertible preferred stock, or straight preferred with equity warrants. ${ }^{196}$ In addition, there are relatively standard liquidation preferences, anti-dilution, and other rights. ${ }^{197}$ Negotiation occurs largely along the kinds of complexity axes described earlier. ${ }^{198}$

One venture capitalist's conception of the contingency he faces in investing is merely a restatement of the gap between "is" and "ought." Thus, "In an ideal world, all of the firm's investments would be winners. But the world isn't ideal; even with the best management, the odds of failure for any individual company are high. On average, good plans, people, and businesses succeed only one in ten times."199 The reason lies in the factors that can go wrong: sufficiency of capital, management's capability and focus, product development going as planned, production and component sourcing going as planned, com-

195. FREUND, supra note 12, at 2, 4-5.

196. Bob Zider, How Venture Capital Works, Harv. Bus. Rev., Nov.-Dec. 1998, at 131, 134.

197. Joseph B. Hoffman \& Richard G. Chisholm, Trends in Venture Capital Financing Terms, Metropolitan Corp. Couns., Apr. 2002, at 14.

198. See Eggleston et al., supra note 12 and accompanying text.

199. Zider, supra note 196, at 136. 
petitors behaving as expected, customers wanting the product, pricing forecast correctly, and patents being issued and enforceable. Assuming that these are independent events, the failure of any single factor means the failure of the company, and even in the best companies the odds are only four to one (eighty percent) on each factor, then the best probability of success is about seventeen percent. ${ }^{200}$

In their study of law firms in Silicon Valley, Mark Suchman and Mia Cahill directly addressed the nature of transactional uncertainty and the rational actor model. ${ }^{201}$ They distinguish "risk"-the probabilistic uncertainty within a known range of options and outcomes-from unbounded "uncertainty"-when neither the full range of options nor the relative probability of alternative outcomes can be known. ${ }^{202}$

Unlike risk, uncertainty is deeply incompatible with the neoclassical model of fully rational decision-making. Instead of producing a careful expected-utility analysis of all lines of action, conditions of uncertainty tend to produce "boundedly rational" decision strategies, involving "good enough" choices, gut feelings, and rules of thumb. At a more macroscopic level, uncertainty elevates transaction costs and exacerbates intra-organizational strains and power struggles. Consequently, unresolved uncertainty poses a fundamental cognitive and organizational obstacle to the formation and maintenance of stable markets for high-technology start-up capital. ${ }^{203}$

As we will see, the contribution of lawyers in this environment is significantly different than the predictors of possible ex post interpretations of their agreements. They are contributors to the creative process-helping to bring their clients a little closer to the ideal world where companies do not fail. ${ }^{204}$

\section{The Question that Derives from the Empirical Observation}

Having reviewed the theoretical limitations of the private law of contracts and the rational actor model to take account of very complex state contingencies, and having observed transactional complexity, of which legal uncertainty is merely a subset of total uncertainty, to what discipline may legal scholars and practitioners turn for expla-

200. Id. For other sources helpful in getting a sense of the breadth of contingency not addressable by law, see BAGLey \& Dauchy, supra note 19, at 1-8; C. Gordon Bell \& John E. McNamara, High-Tech Ventures: The Guide of Entrepreneurial Success (1991); Michael Lewis, The New New Thing: A Silicon Valley Story (2000); Tom Elfring \& Willem Hulsink, Networks in Entrepreneurship (May 2001), available at http://ssrn.com/abstract=37 0887 .

201. Mark C. Suchman \& Mia L. Cahill, The Hired Gun as a Facilitator: Lawyers and the Suppression of Business Disputes in Silicon Valley, 21 LAw \& Soc. INQUIRY 679 (1996).

202. Id. at 688-89.

203. Id. at 689 (footnotes omitted).

204. See infra Part III.C.2. 
nation and guidance? In the following sections, I review two proposed approaches suggested by my earlier summary of moral philosophy, legal pragmatism (moderate and Posnerian) and the limited idealism of Kant.

\section{B. A Critique of the New Orthodoxies}

We can trace the modern legal pragmatism of Judge Posner and others back to the American pragmatists of the late nineteenth century. Justice Holmes was a contemporary, correspondent, and colleague of James and Dewey, and his philosophy of law reflected a shared pragmatism. ${ }^{205}$ Justice Holmes's The Path of the Law is as firm as the writing of Dewey and James in holding experience above abstract ideals in determining what the law should be. ${ }^{206}$

There are two primary ironies in the fact that the self-styled heirs to Justice Holmes reject any role for philosophy in the understanding of contingency. The first is apparent from internecine debates among the legal pragmatists themselves. Those radical pragmatist skeptics, like Judge Posner, who are so firmly wedded to the scientifically derived laws of economics as the one true determinant of human interaction and welfare, are viewed by their more moderate brethren as icons of the very dogmatism that the original pragmatists deplored. ${ }^{207}$ The

205. For an entertaining history of this relationship, see MENAND, supra note 11, at 3-69. Menand observes that Holmes's particular aversion to absolutism was shaped by his experience as a young officer in the Civil War.

206. Oliver Wendall Holmes, The Path of the Law After One Hundred Years, 110 Harv. L. REv. 991, 998 (1997), originally published, 10 HARV. L. REv. 457 (1897). Holmes wrote:

The language of judicial decision is mainly the language of logic. And the logical method and form flatter that longing for certainty and for repose which is in every human mind. But certainty generally is illusion, and repose is not the destiny of man. Behind the logical form lies a judgment as to the relative worth and importance of competing legislative grounds, often an inarticulate and unconscious judgment, it is true, and yet the very root and nerve of the whole proceeding. You can give any conclusion a logical form. You always can imply a condition in a contract. But why do you imply it? It is because of some belief as to the practice of the community or of a class, or because of some opinion as to policy, or, in short, because of some attitude of yours upon a matter not capable of exact quantitative measurement, and therefore not capable of founding exact logical conclusions. Such matters really are battle grounds where the means do not exist for determinations that shall be good for all time, and where the decision can do no more than embody the preference of a given body in a given time and place. We do not realize how large a part of our law is open to reconsideration upon a slight change in the habit of the public mind. No concrete proposition is selfevident, no matter how ready we may be to accept it, not even Mr. Herbert Spencer's Every man has a right to do what he wills, provided he interferes not with a like right Id. on the part of his neighbors.

207. See infra notes $218-234$ and accompanying text. 
second irony is far more subtle. ${ }^{208}$ Both schools of pragmatism, the moderate and the skeptical, reject any role for nonempirical reason in the determination of moral ends, placing Kant's philosophy in that school. Yet a careful reading of Kant, and subsequent and more accessibly written restatements of his philosophy, shows that Kant himself would have rejected the extreme skepticism of Judge Posner as a new dogmatism. ${ }^{209}$ Indeed, we can view Kant's philosophy of contingency as the very pragmatic idealism we would expect to see in a lawyer who is not only capable of deciding and interpreting ex post, but of creating value ex ante.

\section{Legal Pragmatism at War with Itself}

One of the problems in describing legal pragmatism is the breadth of thought subsumed within it, and the number of legal scholars who characterize themselves as legal pragmatists. At least one scholar has attempted to state a common denominator. ${ }^{210}$ Legal pragmatists, like their philosophical antecedents, believe knowledge is "contextual"embodied in language, experience, culture, and practice-and "instrumental" - meaningful only as a tool to solve real problems. ${ }^{211}$ In particular, all pragmatists would reject that part of Kant's philosophy that attributes any ability of reason to access truth or morality (pure or practical reason) either because they deny the existence of an external reality accessible only by reason, or if they do not deny it, they do not believe it has any value in addressing the problems of contingency:

This is not to suggest that the pragmatist denies the existence of a world external to the human mind. For the pragmatist, however, classifying statements as true by virtue of their correspondence to external reality is simply not a productive activity. The pragmatist suggests that we would be better off if we abandoned attempts to ground our beliefs in some external reality, and that the task of philosophers, poets, and scientists (and, I would add, of lawyers and judges as well) is to come up with better ways of helping us to cope in the face of radical uncertainty. ${ }^{212}$

As a general statement, pragmatists employ a methodology in resolving legal issues that rejects the grounding of law in any single overriding value, doctrine, policy, or set of principles. ${ }^{213}$ They look to "practical reason," but not the practical reason that Kant holds may

208. See infra notes $210-217$ and accompanying text.

209. See infra notes $236-266$ and accompanying text.

210. See generally Thomas F. Cotter, Legal Pragmatism and the Law and Economics Movement, 84 Geo. L.J. 2071 (1996).

211. Id. at 2075-79.

212. Id. at 2075-76 (footnotes omitted).

213. Id. at 2082-85. 
access a priori moral imperatives. ${ }^{214}$ It is instead "intersubjective understanding through 'dialogue, conversation, undistorted communication, communal judgment, and the type of rational wooing that can take place when individuals confront each other as equals and participants." 215 And legal pragmatists reject sharp distinctions between ends and means:

[G]oals themselves are never final; "they are at best momentary resting points whose attainment has further foreseeable consequences desirable or undesirable; hence they must themselves be evaluated as means relative to those consequences." Similarly, the means we select to accomplish our ends are not exclusively instrumental; "activities, however instrumentally conceived, are to be evaluated by their intrinsic satisfactions or frustrations as well as by their consequences."216

In short, the moderate and benign view of pragmatism is that it recognizes the complexity of human experience and rejects almost no approach that might aid us in dealing with contingency: "Pragmatism recognizes that no one way of analyzing a problem captures everything, but rather that any method illuminates and privileges some phenomena and some values while obscuring and denying others."217

Legal pragmatism takes a far more acerbic and strident turn in the writings of Judge Posner, whose skepticism is far more radical and absolute than the benign and open spirit of questioning that emanates from other legal and philosophical pragmatics. ${ }^{218}$ His two recent

214. See infra notes $247-260$ and accompanying text.

215. Cotter, supra note 210, at 2087 (quoting Richard Bernstein, Beyond OBJECTIVISM AND Relativism 223 (1983)).

216. Id. at 2093 (quoting Thomas C. Grey, Holmes and Legal Pragmatism, 41 Stan. L. Rev. $787,852(1989))$.

217. Id. at 2141.

218. It is hard not to be overwhelmed by the sheer power of Judge Posner's breadth of knowledge and persuasive passion, part of which, I believe, is the result of his certainty in the rightness of his position. As an example, the following is his assessment of the value of moral philosophy, in a nutshell:

It is because of the importance of distinguishing the moral entrepreneur from other moralists that I define my main target in this chapter as academic moralism. Moral entrepreneurs play a role in the evolution of morality; other moralists do not; and the modern university professor is prevented by the character of a modern academic career from being a moral entrepreneur, with rare and largely irrelevant exceptions. Earlier moralists-the authors of the classic works of moral philosophy, such as Plato, Hume, Bentham, Kant, and Mill-were for the most part not professors (though Kant was) and in any event lived in times when knowledge was less specialized and esoteric and the line between theory and practice much less distinct. The modern moral philosopher is firmly imprisoned in an ivory tower.

Richard A. Posner, The Problematics of Moral and Legal Theory 8 (1999). He also makes typically broad empirical statements about lawyers, judges, and philosophy: "[Orthodox pragmatism] has become a part of technical philosophy, in which few judges or practicing law- 
works, The Problematics of Moral and Legal Theory ${ }^{219}$ and Law, Pragmatism, and Democracy, ${ }^{220}$ set forth a theory that he describes as "pragmatic moral skepticism"221 and apply it to issues as diverse as legal professionalism, ${ }^{222}$ euthanasia, ${ }^{223}$ constitutional theory, ${ }^{224}$ antitrust, ${ }^{225}$ legal positivism, ${ }^{226}$ President Bill Clinton's impeachment, ${ }^{227}$ and Bush v. Gore. 228 While whole armies of scholars are no doubt thankful to Judge Posner for providing a juicy foil, ${ }^{229}$ I address only the very broad issue of "pragmatic moral skepticism" as I believe it impacts addressing contingency in the practice of complex deal law.

What is clear is that Judge Posner's approach to moral philosophy is not even pragmatically agnostic. His is a purely scientific approachdespite his claim to the contrary. He does not object to theory as such: "Economic theory, and the parts of the natural sciences with which I have at least a nodding acquaintance, such as evolutionary

yers take any interest." PosNer, supra note 14, at 41 . "[A]cademic philosophy [is] a field that has essentially no audience among judges and lawyers." Id. at 11.

I hardly consider myself as having been imprisoned in an ivory tower, and would defer to Judge Posner on any empirical observation about the behavior of judges. I do not apply the same level of deference, however, about empirical observations of practicing lawyers. Practicing lawyers do not think about philosophy in their work, on the whole, any more than they consider microeconomics, game theory, chaos theory, or other scholarly attempts to make sense of, and predict, what they do and why. But I do see a connection between moral philosophy and the real world. I have seen real world business executives demonized and ultimately consumed by an inability to reconcile the "is" and the "ought," the randomness of nature against the order our minds attempt to construct around it. I have also seen real world business executives who content themselves with, and find a way to justify, the world as it is. My casual empiricism tells me both fail as leaders. My goal is to place these empirical observations in a scholarly framework at least as legitimate as economic analysis. Outside legal and economics scholarship, Adam Smith is not the only eighteenth century thinker whose ideas are still considered worthy of application to our world; people still read Hume and are persuaded by his skepticism, or read Kant and are moved by his explanation of idealism.

219. See Posner, supra note 218.

220. See Posner, supra note 14.

221. Posner, supra note 218 , at $8-13$.

222. Id. at 185-226.

223. Id. at 128-34.

224. Id. at 144-82.

225. PosNer, supra note 14 , at 234-47.

226. Id. at 250-91.

227. Id. at 213-34.

228. Id. at $322-56$.

229. Problematics and the article on which it was based have generated many thousands of words in response. One issue of Volume 111 of the Harvard Law Review is devoted almost entirely to the original article, reactions of a number of other scholars, and Judge Posner's reply. See generally, e.g., Charles Fried, Philosophy Matters, 111 Harv. L. REv. 1739 (1998); Anthony T. Kronman, The Value of Moral Philosophy, 111 HARv. L. Rev. 1751 (1998); Nussbaum, Still Worthy, supra note 114. Book reviews include John Mikhail, Note, Law, Science and Morality: A Review of Richard Posner's The Problematics of Moral and Legal Theory, 54 Stan. L. Rev. 1057 (2002), and Jeremy Waldron, Ego-Bloated Hovel, 94 Nw. U. L. REv. 597 (2000). 
biology, seem to me both beautiful and useful."230 But as Judge Posner's epistemology is traditionally empirical, his theory is only valid when "it is about observable phenomena and 'real' (physically existing), entities [and] can be tested by comparing the predictions generated by the theory with the results of [the] observation[s]."231 As to what we can know of the world a priori solely by our reason, Judge Posner is a child of Hume: "Neither logic nor any empirical protocol guarantees truth. So even scientific knowledge is tentative, revisable-in short, fallible."232

\section{But as to moral philosophy, there is no doubt:}

230. Posner, supra note 218 , at 13 . Why a committed pragmatic moral skeptic like Judge Posner would express the judgment that a theory is "beautiful" in addition to "useful" is in fact the subject of Kant's Critique of Judgment, the third of his "Critical Works." See generally IMMANuEl Kant, Selections from Critique of Judgment, in BASIC WRITINGS OF KANT, supra note 134 , at 273 . His answer lies in the paradox presented by the fact that our judgment is clearly our own and subjective, yet it purports to look at the world and make an objective statement that the pleasing aspect of the thing observed is universal. In the interest of full disclosure, Hume noted the same paradox, disclaiming any role of reason in assessing the beautiful. See generally David Hume, Of the Standard of Taste, in Four Dissertations (1757), excerpted in PHilosophy: Ba SIC READINGS, supra note 133, at 393-408. He concluded instead that what we perceive as beautiful is simply that which has been so perceived in all ages and all countries. Id. But not everyone, according to Hume, can discern beauty. It is a matter of having "delicacy of imagination," "practice in a particular art," "opportunity of comparing the different kinds of beauty," and "a mind free from all prejudice." Id. Men labor to achieve all of these skills, which alone entitle one to adjudge the "true standard of taste and beauty." $I d$. at 403. Asks Hume, "But where are such [men] to be found? By what marks are they to be known? How distinguish them from pretenders? These questions are embarrassing ...."Id. I leave the answers to those questions to the rational actor theorists.

231. Posner, supra note 218 , at 13 . The devotion to scientific method as the sole determinant of pragmatic truth is echoed in other treatments of law and economics. In responding to Amartya Sen's theory of commitment as an alternative to the rational actor model to explain altruism, Eric Posner wrote: “The problem with Sen's argument ... is that simply assuming that people operate out of principle and rational calculation gives one less methodological purchase than the ordinary rational choice assumptions do, without, as far as I can tell, compensating for this loss by producing a methodological gain." Posner, supra note 5, at 146 . See generally Amartya K. Sen, Rational Fools: A Critique of the Behavioral Foundations of Economic Theory, 6 Phil. \& Pub. Aff. 317 (1977).

232. Posnek, supra note 14, at 6. Judge Posner's epistemology, if not his moral theory, seems to have taken a turn in the four years between Problematics and Pragmatism. In the former, he labels himself a "pragmatic moral skeptic." PosNer, supra note 218, at 8 . In the latter, he claims not only not to be a skeptic, but also to be affirmatively antiskeptical. POSNER, supra note 14, at 7. He claims not to be a radical skeptic because such a person would not be skeptical about his skepticism. Id. Pragmatists, like Judge Posner, apparently merely "doubt that skepticism or relativism can be proved to be wrong." POSNer, supra note 14, at 8 . Contrast this with the absolute and non-skeptical views about moral philosophy described in the text. Note also that the epistemological issue of the skeptic's ability even to pose the skeptical question is the fundamental issue of the Critique of Pure Reason. "What are the presuppositions of experience? What has to be true if we are to have even that bare point of view which the skeptics ascribe to us?" Scruton, supra note 148 , at $28-29$. 
And however all this may be, academic moralism has no prospect of improving human behavior. Knowing the moral thing to do furnishes no motive, and creates no motivation, for doing it; motive and motivation have to come from outside morality. Even if this is wrong, the analytical tools employed in academic moralismwhether moral casuistry, or reasoning from the canonical texts of moral philosophy, or careful analysis, or reflective equilibrium, or some combination of these tools-are too feeble to override either narrow self-interest or moral intuitions. ${ }^{233}$

In this again, Judge Posner descends directly from the skepticism of Hume, who famously described reason as the slave of the passions. ${ }^{234}$

The point is that the very absolutism that spurred philosophic pragmatism appears in the absolute rejection of any role that philosophy might play in explaining contingency and prescribing the role of lawyers in addressing it. Even those who would otherwise describe themselves as legal pragmatists turn squeamish with the elevation of economic theory as the predominant explanatory model of human activity. ${ }^{235}$

\section{The Kantian Critique}

Kant's impulse to his critical philosophy was, by all readings, similar to the impulse of the skeptics or the pragmatists. But it is far more subtle, and more difficult to grasp, and in many ways far more unsatisfying, than either form of dogmatism: An absolutist explanation of everything in the world or an absolutist denial that anything can be explained. Some things can be explained, and some things cannot.

To make this clear, we first need to delve a little deeper into the way Kant explains moral law and how it relates to knowledge. In Kant's famous words, Hume's work awakened him from his "dogmatic

233. POSNER, supra note 218 , at 7 .

234. Susan Neiman, The Unity of Reason: Rereading Kant $34-35$ (1994); see Nussbaum, Still Worthy, supra note 114, at 1776. Nussbaum argues:

Reading Richard Posner's ['Problematics' article] is something like reading Hume's

Treatise with the Hume removed: like, that is, encountering the implausibly mechanistic picture of human personality and the defiant debunking of reason's pretensions without at the same time, and inseparably, encountering the gentle, playful, and many-colored mind, thoroughly delighted by reason and human complexity, incomparably deft in argument, that again and again soars beyond and dives beneath the rigid structures it has erected for itself.

Id. (footnotes omitted).

235. See generally Cotter, supra note 210 , at $2130-35$. In addressing the incommensurability thesis, discussed supra note 167 and accompanying text, "the pragmatist is skeptical about any proposal that sets up economic efficiency as the exclusive, or even predominant, criterion informing a given area of the law .... To believe, as does Posner, that it would be an improvement if all of law could be reduced to instrumental terms is to fall into yet another foundationalist trap." Id. 
slumbers," that is, an unthinking acceptance of the role of reason. ${ }^{236}$ In similar fashion, I will try to respond to Judge Posner's skepticism as Kant did to Hume.

The first pages of The Critique of Pure Reason spell out the problem Kant seeks to resolve. As Hume observes, all of our knowledge begins with experience. ${ }^{237}$ But that it begins from experience does not necessarily lead to the conclusion that all knowledge arises from experience: "It is therefore a question which deserves at least closer investigation, and cannot be disposed of at first sight, whether there exists a knowledge independent of experience, and even of all impressions of the senses?"238

As discussed in Part II, Kant answered the question "yes," but with an explanation. The knowledge claims of reason are limited to that which relates to experience, but reason may make a priori claims of morality. As we will see, it is the same reason. There is a unity in how our reason approaches both truth (as in scientific method) and morality (as in concluding that reason is not a slave of the passions in helping decide what we ought to do). We need not ignore nor deride where our minds may take us, but instead may find an explanation based in reason for the fact that we-skeptics, pragmatists, and idealists alike-even perceive a sense we call contingency (much less the contingency that might be addressed by a legal contract). In short, our reason takes us to a place that is ideal, as we think the world ought to be. The world does not necessarily follow. And that gap, between the "ought" of our reason-how things should turn out-and the "is" of experience-what really happens in the world-is how we define contingency. ${ }^{239}$ For the ploughman and the practical professor, I argue that there is more practical value for the working deal lawyer in this philosophical understanding than the legal pragmatists give credit.

\section{a. The Nature of Reason}

First, we need to understand something about Kant's explanation of the workings of reason. Not being tied to any form of experience, in Kant's view, our reason nevertheless organizes our perception of experience. ${ }^{240}$ It does so through an innate drive to seek the Uncondi-

236. Immanuel Kant, Prolegomena to Any Future Metaphysics, in THE Philosopher's HANDвоOK, supra note 121 , at 389.

237. See supra notes $134-145$ and accompanying text.

238. KANT, supra note 134 , at 25.

239. My discussion of Kant here and in the sections that follow is drawn from NeIMAN, supra note 234 .

240. See id. at 61-62. 
tioned. When we begin to investigate nature, our reason, quite apart from any experience, simply assumes from the outset (a priori) that there are empirical laws governing what we see. Think about our exploration into subatomic particles. We began with the ancient Greeks speculating whether the elements were one or four. Now we are discovering the proton's parts-quarks and mesons, which are held together by forces-the weak force, the strong force, gravity, and electromagnetism. We describe these forces by application of our reason to more and more data, spurred by reason telling us that we still do not have the final and unconditioned answer. As Susan Neiman describes it:

A state of affairs is presented in appearance. Reason is thereupon moved to ask for its conditions, that is, the premises upon which it appears in just this way at just this time. The regress thus prescribed is simply the attempt to explain the ordinary data of experience. A full explanation cannot rest content with the statement of the conditions of the initial state of affairs that demanded it. These conditions, in turn, must be explained, and their conditions, until we reach a point at which no further explanation is conceivable. This point, at which the given would appear as self-explanatory and hence necessary, is the Unconditioned. ${ }^{241}$

All references to the Unconditioned are metaphors; a "horizon" we can approach but never reach. ${ }^{242}$ "If the Unconditioned is the idea of the complete intelligibility of the world as a whole, it is equally the idea that the world as a whole forms a system according to laws." 243 Indeed, as discussed earlier, it forms the basis by which Judge Posner would see not only utility, but beauty, in the derived systematic laws of science or economics. It is one thing to see the behavior of the market; it fills us with satisfaction to be able to explain it elegantly with four lines on a supply and demand graph. ${ }^{244}$

\section{b. Reason and the Scientific Method}

Kant claims that reason demands to systematize what we experience, and these demands form the basis of science, with the following implications:

- We assume that nature as a whole forms a system according to empirical laws. 
- We are able to go beyond present experience to possible experience, and posit truth claims about the unseen (e.g., mesons and quarks).

- We are able to deduce methodological principles that guide the inquiry:

Reason's ability to do this stems from characteristics we have already noted: its role as an autonomous power [independent of experience] gives it the capacity to select the elements of experience that are to be considered as well as, more generally, the capacity to formulate hypotheses that are not simply abstractions of statements derived from experience. ${ }^{245}$

These principles taken together are the philosophical basis for the method Judge Posner so admires-the offering of a hypothesis and the subsequent measurement of its predictive power.

The ultimate irony is the ultimate paradox. Achieving knowledge of the Unconditioned (consider, for example, the issue surrounding teaching Creationism in the schools) would be the end of science. We seek knowledge with a drive that, if successful, would be the end of knowledge seeking.

\section{c. Reason and Morality}

We have not, until now, discussed how Kant viewed the operation of reason in the realm of morality. Unlike scientific inquiry into nature, which seeks to know what is true, morality only requires that we determine what we ought to do. 246

Kant approaches this by way of imperatives. An imperative is not a proposition claiming to be true or false, but claiming to say what we ought to do. ${ }^{247}$ A hypothetical imperative is one that may be true in all states of the world: "Tell a man, for example, that he must be industrious and thrifty in youth, in order that he may not want in old age."248 A hypothetical imperative does not state a moral law-it de-

245. NeImAN, supra note 234 , at $70-75$.

246. See Scruton, supra note 148 , at 84 . Scruton notes:

So conceived, the task of proving the objectivity of morality is less great than that of proving the objectivity of science, despite popular prejudice to the contrary. For the faculty of the understanding requires two "deductions", one to show what we must believe, the other to show what is true. Practical reason, which makes no claims to truth, does not stand in need of this second "objective", deduction. It is enough that reason compels us to think according to the categorical imperative. There is nothing Id. further to be proved about an independent world.

247. KANT, supra note 13 , at 171-72.

248. KANT, supra note 141 , at 227. 
pends on the material and practical end being sought. If you want to go to a top law school, get good grades and score well on the LSAT. But you may not want to, in which case the imperative is not helpful.

In addition to the utilitarian hypothetical imperative, there is also what Kant calls a categorical imperative. In contrast to a hypothetical imperative, a categorical imperative strips away all empirical conditions. ${ }^{249}$ There is no "if" at the beginning. By practical reason, we derive the "ought" statement that should be binding not only on ourselves, but also on any rational person. It is the basis on which I may universalize a rule from my particular wants and needs to a general statement. Make no mistake: I cannot demonstrate the validity of a categorical imperative through empirical testing. It is synthetic-the statement is not simply true in itself-and a priori-it is derived solely by my reason. 250

There can be many categorical imperatives, but Kant focuses on three. The first is so well-known that it is not just a categorical imperative, but is generally referred to as "the Categorical Imperative:" Act in a way that the principle of your action would be, by your will, a "Universal Law of Nature."251

The second is to act so as to treat humanity, whether in my own self or in another's, always as an end and never only as a means. As we must respect the autonomous rational agent that is our own self, we must treat others as autonomous beings and ends in themselves. As Kant emphasized, "Beings whose existence depends not on our will but on nature's, have nevertheless, if they are irrational beings, only a relative value as means, and are therefore called things; rational beings, on the contrary, are called persons, because their very nature points them out as ends in themselves." 252

Finally, every rational being must act as if he or she were both a sovereign and a member of a kingdom of ends. ${ }^{253}$ This recognizes that each of us has a free and autonomous will that is sovereign for us, but which is required to see others, also having a free and autonomous will, as ends. Yet, reciprocally, as to that other, we are the end contemplated by the other's sovereign will. We are thus obligated, even while recognizing that the kingdom of ends is an unattainable ideal, to attempt to achieve it. ${ }^{254}$

249. KANT, supra note 13, at 172.

250. SCRUTON, supra note 110 , at $284-85$.

251. Kant, supra note 13 , at 179.

252. Id . at 185-86.

253. Id. at 190-91.

254. Id. 
The same paradox of science appears in morality. Our reason is capable of describing an ideal world-where the real and the rational are the same, where the "is" and the "ought" coincide-but the world has a stubborn way of not measuring up. Nevertheless, our reason seeks unconditioned and final truths about the linkage, for example, between virtue and happiness. ${ }^{255}$ Reason demands that the world make sense, but experience is random. Reconciling the two, says Kant, is beyond our means.256 As Susan Neiman explains, not only would attainment of the Unconditioned in science end science, but knowledge of a systematic link between happiness and virtue, even if possible, would be morally disastrous. ${ }^{257}$ If we knew the formula that connects virtue and happiness, we would not be able (unless we were saints) to act other than as utilitarians, and in that we would have no free will. The essence of morality is choice, and there is no real choice unless we do not know whether virtue will be rewarded. What makes us moral versus merely good or happy is that we have to choose and not know the reward. 258

\section{d. Reason and Dogmatism}

Finally, there is a linkage among reason, dogmatism, and skepticism. Contrary to the image often presented by the pragmatists, ${ }^{259}$ the notion that we will never know for certain whether goodness is linked to happiness is, paradoxically, humbling and pragmatic. ${ }^{260}$ As Susan Neiman observes, "For Kant, human virtue requires a stance that is demanding and complex: we must guide our actions by an idea of reason, yet any purported assurance that we have attained this ideal would be self-defeating." 261

Consider the following Kantian assessment of Judge Posner's "pragmatic skepticism" and his rejection of philosophy as the "mind on hol-

255. If you believe otherwise, and you are a person who regularly fastens your seat belt in the car, think about your instinctive reaction when hearing about a random death that was not the victim's fault, to find out whether she was wearing her seat belt.

256. Susan Neiman observes about Kant's philosophy: "The gap between nature and freedom, is and ought, conditions all human existence .... Integrity requires affirming the dissonance and conflict at the heart of experience." NeIMAN, supra note 1, at 80.

257. Neiman, supra note 234 , at 129-31.

258. Neiman, supra note 1 , at 67-72.

259. PoSNER, supra note 14 , at 6 (stating that " $[t]$ he consequences that concern the pragmatist are actual consequences, not the hypothetical ones that figure prominently in Kant's moral theory").

260. NeImAN, supra note 234 , at 132.

261. Id. at 131 . 
iday."262 Susan Neiman summarizes the Kantian view of the urge to philosophy as follows:

Human reason is driven to seek the Unconditioned, the thoroughgoing intelligibility of the world as a whole. Coming of age requires not abandoning, but redirecting this search: from dogmatic metaphysics to empirical science, from a theodicy that affirms the social order to a political program that transforms it. ${ }^{263}$

Kant recognized the urge of unrestrained metaphysical meandering as the road to a dogmatic creed, deceived in its belief that it alone had reached the Unconditioned, but wholly or partially untethered to experience.

But the postmodern skeptic (like Richard Rorty, whom Judge Posner hails as a philosophical pragmatist one can understand) ${ }^{264}$ fares no better than the dogmatic absolutist, and Neiman's explanation is worthy of quoting in its entirety:

[Kant's] conception of philosophy is fundamentally different from postmodern calls for an end to metaphysics because it is regulative, frankly directed toward the achievement of enlightenment. The Kantian answer to those who find its justification of that goal unacceptably self-supporting is available in the [Critique of Pure Reason]. Those who assume that if philosophy failed to provide us with certain knowledge, it can, at best, become an instrument of play accept the traditional assumption that only constitutive claims ensure genuine reality. Their rejection of metaphysics is merely the disappointed mirror image of metaphysics itself. This is, I believe, the meaning of Kant's claim that skepticism is simply counterdogmatism [ ]. The skeptic uncritically shares the dogmatist's beliefs about the nature of reason and reality. His rejection of reason and philosophy is based on their failure to succeed in terms of an unexamined and untenable model. Hence, their attitude toward the hope of enlightenment that underlies every attempt at philosophy is as dogmatic as that of those who sought to fulfill that hope by constructing systematic metaphysics. ${ }^{265}$

Professor Charles Fried may have expressed the same thought in fewer words in his response to Judge Posner's Problematics: “As so often happens, the skeptic here is a disappointed absolutist, taking his revenge on the world for depriving him of all the right answers all at once." 266

262. Posner, supra note 14 , at 5.

263. Neiman, supra note 234, at 202.

264. Posner, supra note 14 , at $39-48$.

265. Neiman, supra note 234, at 202 (footnote omitted).

266. Fried, supra note 229 , at 1750. 


\section{Normative Recommendations}

As we turn to normative proposals about dealing with contingency in complex business transactions, I am concerned I may be co-opted by the need to present an argument of utility. I should be advocating that those who agree with me, or leaders who act on the principles I advocate will be more successful, set better policy, maximize social welfare, and bring greater job satisfaction to their employees and a higher return to shareholders. But the nature of my Kantian belief in contingency says there are no guarantees of that-and so we find ourselves in a paradox.

What is the philosopher-deal lawyer to do? Give up trying to produce results in the real world and engage only in speculative musings? Or conclude that the only way he or she can make a difference is to be a utilitarian? I will offer both hypothetical (i.e., instrumental) and categorical (i.e., universal and unconditional) imperatives. As to the former, I will consider the prominent place of something more than pragmatism -indeed, a Kantian limited idealism-in that most instrumental of arenas, business management and leadership (with some slightly non-utilitarian speculation about why there exists such a significant divide between legal and business theorists on the subject of philosophy). As to the latter, I will draw on some examples where I believe a less economic and more philosophical approach for lawyers would be better, both for results and in itself.

\section{Idealism in Modern Management Theory}

The legal approaches to contingency we reviewed in Part II, despite the attempts to bring other disciplines to bear, are largely ex post and directed to legislators or judges. The modern literature of contingency for business leaders is far more robust. ${ }^{267}$ The literature incorporates two fundamental learnings from philosophy. First, there is a persistent call in leadership to what can only be described as idealistic, transcendental, or spiritual values.268 Second, true to the Kantian paradox, if those that are led believed that such appeals were wholly utilitarian, they would not work. ${ }^{269}$ Hence, business executives create

267. I speculate that two reasons explain this. First, there is the philosophically analytic: Leadership is inherent in the concept "business leader." Nobody expects a lawyer to be a leader. Hence, leadership is generally not part of the formal or continuing legal curriculum. Second, I suspect that newly minted MBAs (I will give a pass to the organizational design specialists) are as likely as newly minted lawyers or legal economists to be overwhelmed by the sheer magic of their scientific skills (e.g., valuation techniques), if not the power of profit as motivation to all of the employees of the firm.

268. See infra notes $281-298$ and accompanying text.

269. See infra notes $278-280$. 
value by an appeal to an "ought" whose realization in the world would necessarily bring an end to the impulse for creation of value.

\section{a. The Management-Leadership Revolution}

The business literature stems from a revolution in the philosophies of managing and leading business organizations over the second half of the twentieth century, very little of which appears to have surfaced in the scholarly literature of the law, or in practical manuals for working lawyers. A classic study in modern business literature, The $\mathrm{Ma}$ chine That Changed the World, ${ }^{270}$ recounts the history of this revolution and its impact. After World War II, Japanese industry developed production methods, particularly in what came to be known as the Toyota Production System, to address Japan's global noncompetitiveness. $^{271}$ This newer philosophy of "lean production" and the "lean enterprise" had a decidedly utilitarian outcome: It made mass production systems and organizational designs developed by Henry Ford and Alfred Sloan in the first half of the century obsolete. ${ }^{272}$ By the late 1980s, that obsolescence was a significant contributor to the actual and perceived decline of American industrial leadership. ${ }^{273}$ It triggered a massive American response-the management and productivity revolution of the 1990s (and not coincidentally, the decadelong boom economy). ${ }^{274}$ The irony is that, in substantial part, this revolution of management and leadership had to be something more than utilitarian to succeed.

Compare the Toyota system to the systems Ford and Sloan developed. On the factory floor, "Ford not only perfected the interchangeable part, he perfected the interchangeable worker."275 At General Motors, Alfred Sloan, an MIT graduate, applied the same principles to the organization and management of the enterprise itself; he "would make the system Ford had pioneered complete, and it is this complete system to which the term mass production applies today."276

270. See generally James P. Womack et al., The Machine That Changed the World (1990).

271. See id. at $48-51$.

272. Id. at $44-47$.

273. In his 1985 look back at his work on noncontractual norms, Stewart Macaulay referred to what was legitimately perceived at the time as " $[\mathrm{t}]$ he decline of the American industrial economy." Macaulay, Empirical View, supra note 5, at 472.

274. See generally Paul Ingrassia \& Joseph B. White, Comeback: The Fall and Rise of the AMERICAN Automobile Industry (1995).

275. WOMACK ET AL., supra note 270 , at 30.

276. Id. at 40. 
James Champy, one of the leading exponents of business reengineering, describes the philosophy:

"A great business," said Henry Ford, who knew one when he saw one, "is really too big to be human." The pronouncement, which many people would agree with, begs an interesting question: If a great business can't be human, what can it be? Some image, or metaphor, is called for. . . . And there's not much question what word Ford would have chosen to describe his "great business." He would have called it a machine.

....

... Through Sloan, the ... ideas went well beyond the mechanization of human labor, to the mechanization of management. Sloan imagined, and in fact realized, a management machine, a way to build not just cars, but an entire company. ${ }^{277}$

Now the buzzwords of the lean production revolution are part of the vernacular, and not just in business: empowerment, manufacturing teams and cells, kai-zen (continuous improvement), and kan-ban (justin-time inventory management). ${ }^{278}$ The human impact of lean production on the factory floor, for example, illustrates the change. There are two essential aspects to a manufacturing team: (1) "workers actually adding value" to the product (those on the line) take on "the maximum number of tasks and responsibilities"; and (2) "a system for detecting defects" and quickly discovering their ultimate (not immediately proximate) cause. ${ }^{279}$ The paradox of ideals and utility in the implementation of lean production is apparent:

Our studies of plants trying to adopt lean production reveal that workers respond only when there exists some sense of reciprocal obligation, a sense that management actually values skilled workers, will make sacrifices to retain them, and is willing to delegate responsibilities to the team. Merely changing the organization chart to show "teams" and introducing quality circles to find ways to improve production processes are unlikely to make much difference. ${ }^{280}$

In short, mere practice is insufficient; if the utilitarian aim is transparent, the technique does not work.

\section{b. Idealism and the New Leadership}

The effect of the management-leadership revolution on resuscitating idealism as a means of addressing business contingency is apparent even from the most cursory review of contemporary

277. James Champy, Reengineering Management 11-13 (1995).

278. WOMACK ET AL., supra note 270, at 62, 149.

279. Id. at 99 .

280. Id. 
management literature. ${ }^{281}$ Professor John Kotter of the Harvard Business School is one of the most influential leadership theorists, and his exposition of the differences between management and leadership is a classic in the literature. ${ }^{282}$ It is also consistent with the description of how the business world has changed in the past fifty years.

Kotter sets forth the three primary functions of managers: planning and budgeting, organizing and staffing, and controlling and problemsolving. But he distinguishes management from leadership, highlighting the particular role leadership (as opposed to management) plays in dealing with contingency:

Management is about coping with complexity. Its practices and procedures are largely a response to one of the most significant developments of the twentieth century: the emergence of large organizations. Without good management, complex enterprises tend to become chaotic in ways that threaten their very existence. Good management brings a degree of order and consistency to key dimensions like the quality and profitability of products.

Leadership, by contrast, is about coping with change. . . . More change always demands more leadership. ${ }^{283}$

The respective leadership analogues of managerial skill consist of the following: (1) setting a direction; (2) aligning people; and (3) motivating and inspiring. ${ }^{284}$ Note the perception of an idealistic component to the last element, in particular:

Motivation and inspiration energize people, not by pushing them in the right direction as control mechanisms do but by satisfying basic human needs for achievement, a sense of belonging, recognition, self-esteem, a feeling of control over one's life, and the ability to live up to one's ideals. Such feelings touch us deeply and elicit a powerful response. ${ }^{285}$

The question answers itself: Is this empirical observation better supported by a philosophy of dogmatic skepticism (leading to the conclu-

281. What follows is an unscientific sampling based on a representative selection from the management tomes presently sitting on my bookshelf, collected between the end of 1992 and mid-2004. In addition to those cited in the text, the following works are also instructive in seeing a role for philosophy in leadership that addresses contingency: The Price Waterhouse Change Integration Team, The Paradox Principles (1996) (referring, inter alia, to Soren Kierkegaard, Oscar Wilde, and Alfred North Whitehead on the role of paradox in the management of chaos, complexity, and contradiction); Joseph L. Badaracco, Jr., The Discipline of Building Character, Harv. Bus. Rev. ON LEADERShip, Mar.-Apr. 1998, at 115 (quoting William James regarding the utility of ideas); Nitin Nohria \& James D. Berkley, Whatever Happened to the Take-Charge Manager, Harv. Bus. Rev. ON LeAdership, Jan.-Feb. 1994, at 128 (calling on managers to return to the pragmatism advocated by 19 th century American pragmatists).

282. See John P. Kotter, John P. Kotter on What Leaders Really Do 37-60 (1999).

283. Id. at $52-53$.

284. Id . at 54-62.

285. Id. at 60 . 
sion that we should approach people solely as rational actors maximizing gains) or some kind of pragmatic idealism, grounded in the notion of others as subjects, not objects, and the achievement of a "kingdom of ends"?

Professor Peter Senge, whose principles are laid out in The Fifth Discipline, is perhaps the leading proponent of business as a "learning organization." 286 His work is both a theoretical exposition of human motivation and a practical manual for its use in the workplace. ${ }^{287}$ Without detailing the rubrics under which Senge organizes the principles of a learning organization, ${ }^{288}$ consider the philosophical nature of Senge's take on the contingency of the world:

From a very early age, we are taught to break apart problems, to fragment the world. This apparently makes complex tasks and subjects more manageable, but we pay a hidden, enormous price. We can no longer see the consequences of our actions; we lose our intrinsic sense of connection to a larger whole. When we then try to "see the big picture," we try to reassemble the fragments in our minds, to list and organize all the pieces. But, as physicist David Bohm says, the task is futile-similar to trying to reassemble the fragments of a broken mirror to see a true reflection. Thus, after a while we give up trying to see the whole altogether.

The tools and ideas presented in this book are for destroying the illusion that the world is created of separate, unrelated forces. When we give up this illusion-we can then build "learning organizations," organizations where people continually expand their capacity to create the results they truly desire, where new and expansive patterns of thinking are nurtured, where collective aspiration is set free, and where people are continually learning how to learn together. ${ }^{289}$

286. See generally Peter M. Senge, The Fifth Discipline: The Art and Practice of the Learning Organization (1994).

287. Indeed, The Fifth Discipline generated a separate manual of case studies and practice guides. See Peter Senge et al., The Fifth Discipline Fieldbook: Strategies and Tools for Building a Learning Organization (1994).

288. They are, briefly: "personal mastery" (developing our own abilities to bridge the gap between the current reality and the reality we would like to create); "mental models" (our "deeply ingrained assumptions" and generalizations that impact how we order the world of experience); "building shared vision" (how individual visions of the future can be shared by an entire organization); "team learning" (how we go about tapping all of the intelligence with a team); and "systems thinking" (understanding that the world works in archetype systems that are often beyond our control to influence). SENGE, supra note 286, at 5-16. The Kantian aspects of this philosophy are probably apparent from the foregoing parentheticals; I leave further explication for another time.

289. Id. at 3. In a 1994 article in Fortune magazine, Senge described himself as an "idealistic pragmatist." Brian Dumaine, Mr. Learning Organization, Fortune, Oct. 17, 1994, at 147. His work developed a significant following in corporate America, but also raised some concerns that he was leading a New Age cult: 
But the learning Senge has in mind is, again, more than merely pragmatic or utilitarian: "[I]t is not enough merely to survive. 'Survival learning' or what is more often termed 'adaptive learning' is important-indeed it is necessary. But for a learning organization, 'adaptive learning' must be joined by 'generative learning,' learning that enhances our capacity to create." 290 Adaptive learning has to do with the "is" of current reality and the contingent future. Generative or leadership learning has to do with the "ought" of an ideal worldone without contingency.

Finally, in Senge's conception of our own growth (what he calls personal mastery), he cites a poll pointing to "a "basic shift in attitude of the workplace' from an 'instrumental' to a 'sacred' view of work." 291 Senge observes:

The instrumental view implies that we work in order to earn the income to do what we really want when we are not working. This is the classic consumer orientation toward work-work is an instrument for generating income. Yankelovitch uses the word "sacred" in the sociological not religious sense: "People or objects are sacred in the sociological sense when, apart from what instrumental use they serve, they are valued for themselves."292

This is almost a restatement of Kant's notion of free will and autonomy of the self-the dualism between the empirical world of physical cause and effect and the domain of reason-where the essence of morality is reasoned choice. We work because it is the moral thing to do.

With Michael Hammer, James Champy advocated a business change model called "reengineering": Drastic reshaping of business processes that threw out theories of organizing work (e.g., the division of labor, elaborate controls, the need for managerial hierarchy) dating back to the dawn of the Industrial Revolution. ${ }^{293}$ Two years later, Champy revisited the subject, asking why reengineering had not worked in many cases. ${ }^{294}$ Champy noted the difficulty with which managers let go of the image of factory and organization as machine:

Senge fears that being tarred with the New Age label will hurt the careers of those pioneering managers trying to spread the learning organization within their traditional corporations. But maybe Senge worries too much. Says Ford's [Fred Simon, a senior platform manager], a big Senge fan: "Anybody who comes into my office doing a folk dance is fired."

Id.

290. Id. at 14.

291. Id. at 144.

292. Id.

293. See generally Michael Hammer \& James Champy, Reengineering the Corporation: A Manifesto for Business Revolution (1993).

294. See generally CHAMPY, supra note 277. 
Don't dismiss this notion [of the machine] too fast. It had, and continues to have, tremendous appeal to all of us. Why? Because it is an ideal, a vision of perfected human activity. Human beings are just fine; we wouldn't be anything else. But we are undependable: We get distracted, tired, angry, lusty, and ornery. We get depressed, we're drawn this way and that, grumbling about doing what's good for us. We scheme and battle. Organizational machines, or so the metaphor wants us to believe, do not suffer from any of these disabilities. ${ }^{295}$

What reengineering requires, says Champy, is more than letting go of command-and-control.296 It requires abandonment of faith in an eternal, universally right way of doing things (or the illusion of one conclusive solution to any business problem), but retention of faith in human beings: "the knowledge and belief that we are all eager to learn, and capable of dedication, high spirits, and individual responsibility."297 Finally, Champy observes what we have previously described as the Kantian paradox:

"At the end of every day of every year, two things remain unshakable," Roberto C. Goizueta, chairman and CEO of Coca-Cola Co., says. "Our constancy of purpose and our continuous discontent with the immediate present."

Note the contradiction, the inconsistency, the zig and the zag between constancy and discontent. No hobgoblins, no corpses hold back this company .... Somebody once said that the best sign of intelligence is the ability to hold two good, but contradictory ideas in one's head at the same time. More is required of management today than intelligence. Character is required, and the best sign of it - the reengineering character anyway-is not only to hold two good, contradictory ideas, but to act on them. ${ }^{298}$

How do we explain this significant gap between, on one hand, the contingency philosophies inherent in legal scholarship, where the prevailing views range from moderate pragmatism to radical skepticism and, on the other hand, philosophies of contingency inherent in modern management theory that range from a moderate pragmatism to Kantian dualism to a significant dose of idealism? I suggest the answer lies in a thought expressed above. Legal scholars have difficulty escaping the multiple bonds of the legal model, the new orthodoxies of economic analysis, and the prevailing hindsight view that is peculiar to judges and to the way we teach the law by the reading of litigated cases. Because lawyers play on business turf in the creation of deals, and business people play on legal turf in the later litigation, theory

298. Id. at 38. Cf. Lipshaw, supra note 3. 
about ex ante creation versus ex post interpretation is largely relegated to business thinkers.

\section{Idealistic, Pragmatic, and Creative Lawyers}

The lesson of business leadership theory is that there is a place for idealism in the empirical and instrumental world. Great business leaders envision a world as they want it to be (ideal-as it ought to be) but are not consumed by the fact that things do not always work out as they should. They understand and adapt to contingency, but not as skeptics or even pragmatic skeptics. ${ }^{299}$

Moral philosophy offers practicing lawyers several categorical imperatives. Our reason is capable of letting us see how to bridge the "is" and "ought"- to see the ends of a deal as well as the means to get it done. One of the deans of the academics of entrepreneurship, William Sahlman, has also aptly described a kind of pragmatic idealism that is distinct from reliance on legal or economic models. ${ }^{300}$ Sahlman disdains entrepreneurs and investors smitten by valuation methodologies and deal terms, noting that entrepreneurs naively seek passive investors, like doctors and dentists, rather than sophisticated venture capitalists who demand control and a larger share of the returns. ${ }^{301}$ Sahlman observes, "New ventures are inherently risky, as I've noted; what can go wrong will. When that happens, unsophisticated investors panic, get angry, and often refuse to advance the company more money. Sophisticated investors, by contrast, roll up their sleeves and help the company solve its problems." 302 Moreover, the optimum approach to contingency is not found in complex ex ante contracting:

Often, deal makers get very creative, crafting all sorts of payoff and option schemes. That usually backfires. My experience has proven again and again that sensible deals have the following six characteristics:

- They are simple.

- They are fair.

- They emphasize trust rather than legal ties.

- They do not blow apart if actual differs slightly from plan.

- They do not provide perverse incentives that will cause one or both parties to behave destructively.

299. Pragmatism is simultaneously criticized and defended, and both views are consistent with the idea that pragmatism simply refuses to recognize the role of our reason in driving us to the "ought" of the ideal world. The criticism is that pragmatism privileges the status quo and the prevailing political ideologies. The defense is that pragmatism provides a philosophical basis for gradual and incremental changes. Cotter, supra note 210 , at $2073 \mathrm{nn} .9-10$.

300. William A. Sahlman, How to Write a Great Business Plan, Harv. Bus. Rev. On LeaderSHIP, July-Aug. 1997, at 98.

301. Id. at 107.

302. Id. 
- They are written on a pile of papers no greater than onequarter inch thick. ${ }^{303}$

When a practicing deal lawyer sees more than the model of the law or the rational actor, he or she becomes a participant in the creation of value. In Silicon Valley, successful venture capital lawyers have managed to discard that "inflated 'rights consciousness' that disrupts more flexible and consensual extralegal relationships."304 They absorb uncertainty by being creative in their fee structures ${ }^{305}$ and their approach to opinion letters. ${ }^{306}$ By the clients they take on and encourage, these lawyers help determine which entrepreneurs obtain financing. ${ }^{307}$ They often serve as the first business advisor the entrepreneur has ever had. ${ }^{308}$ They create market standards for deal terms. ${ }^{309}$ Effective M\&A lawyers engage in the "creative discovery of common ground." 310 They act as wise counterweights to their clients, offering "persistence" toward the goal when necessary and "perspective" when appropriate. ${ }^{311}$

What we accomplish by means of our reason in crafting deal solutions is our handiwork. In her article on the process by which judges make decisions, Linda Ross Meyer has defended practical reason, challenging postmodern and pragmatic rejection of all theory, and she builds a bridge from philosophy to practice. ${ }^{312}$ Her use of Heidegger's explanation of thinking is one of the only allusions to the process of $e x$ post legal interpretation I find to be equally applicable to ex ante dealmaking. Heidegger compared thinking to handiwork to make the point that there is a fundamental relationship between thinking and the physical world that is prior to, in Kantian terms, pure or practical reason: "If he is to become a true cabinetmaker, he makes himself an-

303. Id.

304. Suchman \& Cahill, supra note 201, at 680 (footnote omitted).

305. Id. at 691-94.

306. Id. at 694-97.

307. Id. at $698-99$.

308. Id. at $699-702$.

309. Id. at 702-03.

310. FREUND, supra note 12, at 18-21.

311. Id. at 25-26. See Petzinger, supra note 168, at 186-87 (describing how Arthur Liman summoned the courage to act as a counterweight to Hugh Liedtke's rage in the midst of the Getty/Pennzoil negotiation). Petzinger writes:

Liman did not relish calling across the street to the Waldorf and telling his client that he couldn't even get the new proposal inside the four walls of the boardroom. Even to a high-powered lawyer like Liman, "Chairman Mao" was an intimidating figure. But Liman dialed the phone anyway and got Liedtke up from the lunch table. Liedtke let loose a chain of expletives.

Id.

In the face of the tirade, Liman drew his breath.

312. See generally Linda Ross Meyer, Is Practical Reason Mindless?, 86 Geo. L.J. 647 (1998). 
swer and respond above all to the different kinds of wood and to the shapes slumbering within wood." 313 Meyer transposes the allusion of cabinetmaking as practice to thinking as practice:

Practice is significant and meaningful; the "working relations" between persons and persons, and between persons and things, give meaning. Practice allows things to be "as" something else, allows for "like" cases and "relevant" precedents, signs, and symbols. Hence practice, thought of as the relations we see in our experience of working in the world, is significant, because significance is the tracing of connections. These connections make possible what we do-they are the shapes slumbering in the wood, the potential tent in the blanket, the music that a vibrating string in a mathematic and artistic tradition makes possible. The possibilities that we see when we make cabinets and when we judge cases are given to us from the past, not made by us. They are not just morally neutral or premoral possibilities waiting for us to price and evaluate them, but they are already-directed ways which form and inform any abstract discussion of ethical theory. ${ }^{314}$

Part of my practice is counseling naïve entrepreneurs about a dilution structure that will cause them to get, percentage-wise, a smaller piece of a growing pie, but one that grows in absolute size. Another part is hearing my client in a deal negotiation propose a solution that is far too broad for the problem and hearing the other side do the same in response. In each case, the possibilities I bring to the table are the shapes I see slumbering in the wood-out of the dreams and expressions of my clients and others, I craft the cabinet of a deal.

Meyer's own normative recommendations about the marriage of theory to practice (directed largely to judging) are echoed in Freund's comments about practice: It "often boils down simply to a matter of 'feel,' based on experience-as to where, for example, a particular line can and should be drawn, to compromise opposing viewpoints while adequately protecting each of the parties." 315 The "technological colonization" of the law is unlikely to help us understand or teach "feel;" but the study of theory, in this case, philosophy, can "point out important legal concepts left behind ... [and] the consequences of [ ] technological thinking."316

Our reason is capable of turning us into dogmatists, in our lives generally or in a conference room specifically. The same gift-the drive

313. Id. at 654-55 (quoting Martin Heidegger, What Is Called Thinking 14 (Fred D. Wieck \& J. Glenn Gray trans., 1968)).

314. Id. at 656 .

315. See Freund, supra note 12 , at 2.

316. Meyer, supra note 312, at 673-74. Expressed in far less technical terms, we are awash in information. That is one degree removed from knowledge, and still another from wisdom. 
to find the Unconditioned-that makes us look for universal laws of nature and morality contains a curse if we give it too much credit. When faced with paradoxical choices between competing and mutually exclusive values (individual or team, data or intuition, doing it fast or doing it right, justice or mercy), we have three alternatives. We can drive to one pole or the other, or, as writer F. Scott Fitzgerald suggested, hold both opposing views in the head at the same time and still maintain our ability to function. ${ }^{317}$ Of the three, the third is the most difficult to adopt as a day-to-day operating philosophy, precisely because reason itself rebels against it and continues to seek the Unconditioned. Theodicy explains or justifies evil, and, even in the third millennium, the phrase "God's will" continues to be comforting and meaningful to saints and sinners. For most of the Western intellectual class, however, theodicy went out over two hundred years ago, leaving us with only two alternatives: Wake up each morning to face the day holding two opposing views in mind or divide the world into the force of good (usually us) and the independent world of evil (usually them). You may not be any happier or more comforted in the latter case, but at least you will be right. 318

The same dogmatism haunts the negotiating table, and regularly shows itself in the rigidity or obstinacy of both lawyers and clients. Deal-killing occurs when we need to be right, regardless of the practical risk or the present consequence. Pragmatism leaves us flexible enough to avoid the problem, but idealism is the energy behind creativity. Pragmatic skepticism is wonderful for hindsight and nit-picking, but hardly the stuff of moving forward. ${ }^{319}$

317. Quotation Details, The Quotations Page, at http://www.quotationspage.com/quote/90. html (last visited Apr. 4, 2005).

318. This is my thesis for the current state of electoral politics. It is difficult to sit in the middle of the road anymore, holding perhaps but not exclusively the following mellange of viewpoints: hates the idea of an abortion but supports the right to choose; supports gay civil unions but not marriage after long internal debate about what is "normative"; believes we were right to take out Saddam Hussein but wishes we had brought Europe back into the fold when we were done; loves Starbucks but drives a hybrid gas-electric car; cringes at the idea of organized prayer in schools or the crèche on the city hall steps but has a deep and abiding faith; and, while he is thrilled with neither, doesn't understand why the left hates the very person of George W. Bush any more than why the right hated the very person of Hillary Clinton. Ironically, I suspect that Judge Posner would agree with my foolish inconsistency, but insist that only his brand of pragmatism protects against this dark side of reason. I prefer to continue my struggle with the "is" and the "ought", even if I know there is no resolution to be had.

319. See France, supra note 12 , at $88-90$, on the common prejudice in the business world that lawyers make bad corporate leaders:

Often unschooled in accounting or finance, lawyers start their careers in a strange world where risk is frowned upon, colorful marketing is unethical, people rarely work in big teams, and nobody makes a decision without reviewing stacks of paperwork first. 
We should undertake a moral approach to our involvement in the dealmaking process-to see each other as subjects and not objectsand do so because it is worthy in itself, and not because it is guaranteed or even more likely to produce utility. Relevant here is the brilliant and moral work of Jonathan Cohen on the varied forms of rationality in negotiation, ${ }^{320}$ and negotiating with respect. ${ }^{321}$ As to the latter, he persuasively argues the a priori thesis that there is a general moral duty to respect other people-a duty that is not overridden by the fact of negotiation or the various justifications that people might find in the course of negotiations for not treating others with respect. ${ }^{322}$ His thesis - that we are morally obliged to see each other as subjects and ends, not as objects and means-is, as he recognizes, fundamentally Kantian. ${ }^{323}$ How might this surface in practice? I offer two hypothetical situations. ${ }^{324}$

Situation 1: A lawyer represents a company in the automotive aftermarket manufacturing and distribution business. The company makes and sells spark plugs and filters under some well-known brand names. In Mexico, there is a filter company with which it is negotiating a distribution joint venture. After six months of tough negotiating and on the eve of signing a contract (without any indicia of a deal as there was in the Getty/Pennzoil negotiation), the businessperson in charge of the deal says to the lawyer, "We have just come up with an alternative joint venture partner, and, now that we think about it, it's really a better deal. Is there any reason why we can't do it?" The legal model has an easy answer: There is no reason not to go with the second deal. The answer of the rational actor/economic model is more difficult to determine: It depends whether the theorist can really construct an economic model incorporating all the state contingencies of behavior that we may characterize as legal yet opportunistic. Both

Risk aversion can be another problem. People who go to law school rather than Bschool tend to be more cautious. After all, they're choosing a career that holds out the prospect of a guaranteed good income - rather than a small chance of a spectacular one. What's more, the main goal of business lawyers is not to maximize profits but to minimize danger. "Good CEOs have to be able to make tough, bold decisions in the face of uncertainty - and that's hard for lawyers," says James C. Gaither, a former corporate attorney who is managing director at the Silicon Valley firm Sutter Hill VenId. tures. "Lawyers want to keep working until they find the perfect answer."

320. See generally Jonathan R. Cohen, Reasoning Along Different Lines: Some Varied Roles of Rationality in Negotiation and Conflict Resolution, 3 HARv. Negotiation L. Rev. 111 (1998).

321. See generally Cohen, supra note 57.

322. See id. at 750-51.

323. Id. at $751 \mathrm{n} .26$. Cohen does not suggest, however, that Kantian philosophy is the only way to arrive at the conclusion that we are morally obliged to respect others.

324. Both of these situations are derived from transactions in which I participated. 
are valid ways to approach the issue, but there is a third approach, and it involves seeing the other party as subject and end, and not merely object and means. So the lawyer says, "There really isn't a legal claim from potential partner 1 , but that's a minimal standard in any case. Whether or not you have actually signed the contract, is this an area in which you can afford to act opportunistically? And is your calculation based on a good utilitarian model? Partner 1 will be angry. Have you really thought through whether the benefit received from Partner 2 will exceed the pain of extracting yourself from Partner 1? But most importantly, is that how you want to do business? What do you think the right thing to do is? How would you react if the situation were reversed? And how does that factor into your analysis?"

Situation 2: You are the in-house lawyer for a diversified multinational company. The company (Seller) has signed a definitive agreement to sell its micro-widget division for one billion dollars to a relatively new, growing player in the widget industry (Buyer). You and your business colleagues at Seller know that Buyer's executives have been scraping together financing in about the same way you scrounge around the house for money when it is time to pay the babysitter late on a Saturday night and you are out of cash.

One provision of the post-signing covenants in the definitive agreement says Seller may factor the division's accounts receivable until the closing. In practice, what this means is that Seller sells the accounts receivable to a bank (a factor) for a small discount, and takes the cash out of the business. Under the framework of the agreement, it all should work out in the wash, because the post-closing adjustment, which compares the net assets of the division as of the closing with a base line net asset figure, should account for it. Hence, if Seller factors $\$ 50$ million in receivables, it will owe the Buyer that $\$ 50$ million (plus interest) in about six months when the parties resolve all the post-closing adjustment claims.

The only problem is, unbeknownst to Seller, the Buyer's financing is conditioned on the accounts receivable being there to help finance the business over those intervening six months, and because of what Seller did (perfectly permissible under the contract), $\$ 50$ million will be missing from the business. The Buyer will be in breach of loan covenants from the day it first owns the business, and perhaps even insolvent in the equity sense (unable to pay bills as they come due).

The Buyer is not particularly deal-savvy. Its lawyers and finance people did not pick up the issue in the contract. Its treasurer did not react a week prior when Seller's treasurer said he was going to factor the receivables. Now, at the closing on a Friday afternoon, only an 
hour before the federal wire for the transfer of inter-bank funds shuts down, Buyer's CEO and CFO tell you they cannot close unless Seller agrees to put $\$ 50$ million dollars cash back in the business. Buyer has no contractual right to make that demand, and the contract provides for an unsecured $\$ 150$ million in liquidated damages if the Buyer does not close by the end of business that afternoon. You can see the sweat dripping off the Buyer's CEO and CFO. They tell you either to put the money back into the business or to sue us for the $\$ 150$ million. Your own CFO is on the other end of a phone line, railing on and on about how stupid the Buyer is, and how he, the CFO, had a legal right to factor the receivables.

What do you do? Apply the legal model? A legal rationalist, enamored of the state contingencies anticipated in the contract, regardless of what the world turned out empirically to be, might well turn to the remedies anticipated by the contract. Apply an economic model? I suspect even the brightest economist will not be able to compute that many moves and consequences that quickly. Apply the categorical imperative? Maybe there is some intuitive sense of how one would act in this situation if one could will what any person would want the universal rule to be-that is, if the positions were reversed.

I submit that there is no scientific or social scientific model that provides answers in either of these situations. The solutions lie in creativity, vision, and leadership that are beyond mere pragmatic skepticism and economic models.

\section{CONClusion}

My claim about the positive role of philosophy in explaining behavior and setting norms should not be overstated. I do not claim that there are no ex ante concerns about ex post judicial interpretation. To the contrary, good deal lawyers think not only about the document, but also about the drafting history. For example, if my redraft suggests a clarification of ambiguous language, and you reject it, am I worse off than before? That is, would a court consider that fact to be my acknowledgment that your interpretation is correct if what we really want to do is agree to disagree? I am only suggesting that philosophy has something to say about creativity and leadership in the interpersonal process of closing very complex matters-here, the transfer of, or creation of, businesses.

This Article has not addressed an important issue which deserves further thought. I do not address issues of the morality of the transactions themselves, or the conditions that have necessitated them. Assume the following hypothetical. I am brought in as the CEO of a 
company, the demand for whose product (i.e., buggy whips, mainframe computers, or VCRs) has diminished almost overnight because of the rapid appearance of a superior substitute. I determine that there is no option but to write off some assets and sell others. The consequence will be that 2,000 people will be laid off, but for 8,000 others, the business and their jobs have a chance to survive. I do not discuss here the moral implications of the decision to do so. ${ }^{325}$

In this Article I have argued that the narrow confines of the law relating to commercial contingency and the strictures of the law and economics model that dominate contract theory are insufficient to explain contingency in complex transactions or to guide lawyers in dealing with it. Practicing deal lawyers would be well served by looking to philosophy, particularly Kant's views on the uses and limits of reason, in addition to welfare economics and game theory for cross-disciplinary normative proscriptions. Finally, I have suggested that lawyers who are legal or economic dogmatists, seeing the world only as they want it to be, or who are only pragmatic or empirical, and acknowledge only the world as it is, will be far less effective in the highly contingent environment where contracts create more moral than legal markers. The most effective real world deal lawyers will be prepared to address contingency and counsel their clients pragmatically, but with far more idealism than current proponents of the jurisprudence of either legal pragmatism or "pragmatic moral skepticism" have acknowledged.

325. I have a tentative thesis, but it is a work in progress. In short, I am willing to concede the simultaneous operation of economic laws and moral laws. They are, respectively, the embodiments of the critical distinction in Kant between the nature of instrumentality and the nature of free will or autonomy. Our needs in everyday life are fulfilled by instrumental relationships all the time. Discernable physical and economic laws govern the satisfaction of what Kant calls our inclinations (our tangible and intangible needs). The principle of microeconomics that holds that a rational firm will shut down the plant when the marginal cost exceeds the marginal revenue is morally neutral (at least it is to me, but I recognize others, socialist or critical legal theorists, for example, may disagree). The moral questions, on the other hand, are: At the time reality compels your action, are the employees persons or things to you? How do you handle the layoffs? Do you provide outplacement? Is the severance sufficient? Have you developed your employees so that they have transferable marketable skills?

The "rules of the deal" are one thing. Harder cases, like the oxymoronic subject of the "rules of war" (e.g., Abu Ghraib, acceptable collateral damage, the role of evil, good or absent intention when great harm is inflicted) are another. The issues are related, but discussing them here trivializes the real issues of evil. For a far better discussion of that issue, see Neiman, supra note 1. For a libertarian parsing of a purely utilitarian approach to using others as instrumentalities, see Robert Nozick, Anarchy, State and Utopia 35-42 (1974). 